\title{
TORT LIABILITY OF OCCUPIERS OF LAND: DUTIES OWED TO TRESPASSERS
}

\author{
FLEMINIS JAMES, JR, $\dagger$
}

THE scope of duty in negligence cases ${ }^{1}$ is coming increasingly to be measured by the famous formulation:

\begin{abstract}
"Whenever one person is placed by circumstances in such a position in regard to another that every one of ordinary sense who dicl think would at once recognize that if he did not use ordinary care and skill in his own conduct with regard to those circumstances, he would cause danger of injury to the person or property of the other, a duty arises to use ordinary care and skill to avoid such danger."'
\end{abstract}

One of the situations in which the application of this test has been conventionally denied, however, is where plaintiff has voluntarily placed himself within reach of the effects of defendant's failure to take precautions. ${ }^{3}$ The chief example of such a situation is the case where plaintiff voluntarily comes upon land occupied by defendant, and is injured there by a dangerous condition of the premises or by some activity of the occupier. ${ }^{4}$

The judicial approach to this problem, formulated during the course of the 19th century and still providing the point of departure for modern reasoning, divides persons entering land into classes, and graduates accordingly the duties owed by the land occupier.5 Under the conventional approach, the three classes of entrants onto land are trespassers, licensees, and invitees. Those who enter land without the occupier's permission or any other right to do so, are trespassers. To them, the occupier owes no duty with reference to the condition of the premises, save this : he must refrain from intentionally

†Lafayette S. Foster Professor of Law, Yale Law School. The author gratefully acknowledges the assistance rendered by Mr. Gordon B. Spivack, Class of 1955, Yale Law School.

1. James, Scope of Duty in Negligence Cases, 47 Nw. U. L. Rev. 778, 779-80 (1953).

2. Heaven v. Pender, 11 Q.B.D. 503, 509 (1883).

3. BoHlen, Studies in the LAw OF ToRTs 36 (1926); James, Assumption of Risk, 61 YALE L.J. 141, 142 (1952) ; James, supra note 1, at 780.

4. See generally, Eldredge, Modern Tort Problems, cc. 5, 7 (1941); HArRer, Law of Torts $\$ \$ 88-9$ (1933) ; Prosser, Torts $\$ \$ 77-9$ (1941) ; Restatenent, Tonts $\$ \$ 329-50$ (1934); Green, Landowner v. Intruder; Intruder v. Landowener. Basis of Responsibility in Tort, 21 Mich. L. REv. 495 (1923). The problems of the land occupier's duty to thoso outside the premises, e.g., those on adjoining land or on the highway, do not concern persons who have voluntarily encountered the risks of defendant's failure to take precautions.

5. 38 Axr. Jur., Negligence $\$ 92$ (1941); 65 C.J.S., Negligence $\S 23$ (1950). See also authorities cited note 4 supra. 
arranging the premises, e.g., setting spring guns, so as to constitute a trap for the trespasser. As to his activities on his land, the occupier may generally pursue them without reference to the possible presence of trespassers, though he may not intentionally injure a trespasser. ${ }^{0}$ Licensees- "gratuitous," "bare," or "mere"-enter land with the occupier's permission but only for their own purposes which are not connected with the occupier's interests. To them the occupier owes a duty to warn of concealed dangers of the premises which he actually knew about, and a duty to refrain from unreasonably dangerous actize conduct-which would generally mean to take reasonable precautions in carrying on activities which might be injurious to licensees. $^{7}$ There is some dispute as to the essence of what malkes a man an invitee. Some believe it lies in conduct by the occupier, e.g., an arrangement of the premises, which would encourage people to enter the land with a sense of assurance that it had been prepared for their safety. ${ }^{8}$ Others find a need for the visit to serve the business interest and pecuniary gain of the occupier. ${ }^{9}$ Whatever the test of an invitee, the occupier owes him the affirmative duty of care to discover conditions of the premises that may be unreasonably dangerous for the invitee, and either to remedy the defect or acquaint the invitee with the danger. ${ }^{10}$ The occupier also must refrain from conduct which is foreseeably and unreasonably dangerous to his invitee. ${ }^{11}$ Throughout the judicial consideration of these duties to trespassers, licensees, and invitees, the distinction between misfeasance and nonfeasance is recurrently drawn, and a duty of care is more readily found where defendant's conduct is viewed as involving dangerous activity than where it is looked upon as a mere failure to take affirmative steps for plaintiff's protection. ${ }^{12}$

6. $3 \S$ AM. Jur., Negligence $\S \S 109-115$ (1941) ; 65 C.J.S., Negligence $§ 24$ (1950). Sce also authorities cited note 4 supra, and pp. 174- $\$ 2$ infro. The statements made at this point in the text are oversimplified and do not reflect modifications and develogments that have taken place since their original formulation. This is deliberately done not to indieate the author's approval of the conventional approach but rather for the dual purpose of highlighting the modifications and developments, and having the analysis here follow wellmarked patterns of professional thought, for the convenience of the reader.

7. $3 \$$ A.r. Jur. Negligence $\$ \S 104-10 \$$ (1941); 65 C.J.S., Negligence $\$ \$ 32,35$ (1950).

8. Sweeney v. Old Colony \& Newport R.R., 92 A1ass. (10 Allen) 368, 87 Am. Dec 644 (1865), is an early leading case. See Prosser, Busincss lyisitors as:d Iscritces, 20 MIINN. L. REv. 573 (1942), in which the author criticizes his own previous position in Prosser, TORTS $\$ 79$ (1941).

9. Bonlen, op. cit. supra note 3, cc 2, 3. See also Restateriers, Turts $\$ 32$ (1934), and accompanying comment.

10. 38 Ax. Jur, Negligence $\$ 96$ (1941); 65 C.J.S., Negligence $\$ 45$ (1950). Sce also authorities cited notes 8 and 9 sitpra.

11. See authorities cited notes 8-10 supra.

12. BonLEN, op. cit. supra note 3, c. 2; Notes, 156 A.L.R. 1220 (1945), 49 id. 773 (1927) ; Restatexient, ToRTs $\$ \$ 329-50$ (1934) (noting throughout those scetions a distinction between conditions of premises and activities). 
From this thumbnail sketch of the graduated duties conventionally said to be owed by an occupier of land, it may be seen that to no entrant would the occupier owe the full duty of using reasonable care under all the circumstances. To the trespasser no duty of care would be owed at all, but only an obligation to refrain from more grievous types of wrong. To the licensee no duty of care would be owed to discover dangers that lurk in the premises. Even to the favored invitee the occupier would fully discharge his duty if he pointed out a dangerous defect, instead of using care to remedy the conditions. Thus, a man could say to his milkman: "Here is my path, icy and slippery and dangerous. I have no intention of scraping or sanding it. If you want to deal with me, take it as it is; if you don't, I'll take my custom elsewhere."

As we shall see in examining these situations in greater detail, various justifications have been advanced for different aspects of the rules. But the consensus of modern opinion is that the special privilege these rules accord to the occupation of land sprang from the high place which land has traditionally held in English and American thought and the still continuing dominance and prestige of the landowning class in England during the formative period of this development. ${ }^{13}$ This sanctity of land ownership included notions of its economic importance and the social desirability of the free use and exploitation of land. Probably it also included, especially in England, more intangible overtones bound up with the values of a social system that traced much of its heritage to feudalism.

It would be surprising, however, if the general trend over the last one hundred years towards wider accident liability had left the land occupier's citadel untouched. It has not. The tendency of the law, here as elsewhere, has been towards an ever fuller application of the requirement of reasonable care under all the circumstances, and this tendency has included something of the leavening which has taken place generally within the negligence principle itself so as to make it approach a system of liability without fault. ${ }^{14}$ Of course, this process is not complete-and may indeed never be completed. But it marks contemporary developments, which we shall now proceed to examine. The present article will treat the duty to trespassers; a forthcoming article will deal with that owed to licensees and invitees. Throughout both articles will run an inquiry into the validity of these classifications and the system of liability based on them.

\section{Those Protected by the Restrictive Rules as to Duty}

Primarily it is the one in possession of real estate-the occupier-who is protected by the special rules of immunity. The occupier may be, and very

13. Sec, e.g., Johnson v. Patterson, 14 Conn. 1, 6 (1840); Humphrey v. Twin Stato Gas \& Electric Co., 100 Vt. 414, 418, 139 At1. 440, 442 (1927). See also Boml.s, op. cit. supra note 3, at 46; ELDREDGE, op. cit. supra note 4, at 164.

14. The development is traced in Ehrenzweig, Negligence Without FuUlt (1951). 
often is, the owner; but he need not be. If the property is leased, for instance, the tenant is in possession and the owner may indeed be a trespasser during the term of the lease. ${ }^{15}$ Again, the adverse possessor of premises may have the benefit of these special rules as against those whom the law regards as trespassers, licensees, or invitees, as to him. ${ }^{10}$ Moreover, the occupier's immunities probably inure to members of his family ${ }^{17}$ and also to those acting in his behalf on the premises either as employees ${ }^{18}$ or as independent contractors. ${ }^{19}$

A question has arisen whether a licensee, an invitee,,$^{00}$ or the holder of an easement on the land of another may invoke the occupier's immunities as against other entrants onto that land, c.g., trespassers or bare licensees. If the source of that immunity is the unlikelihood of the trespasser's presence, so that the possessor, in using his property, "is not chargeable with that reasonable anticipation of harm to others which in such a case as this is the basis of liability in negligence," rule in favor of the licensee, invitee, or holder of an easement. The plaintiff's presence, or injury to him, is generally no more foreseeable to such a defendant than it would be to the occupier himself. But this, as we shall see, is an unsatisfactory reason for the immunity of the occupier; it would be even less satisfactory as a basis for immunity of others. And if immunity originated in an overzealous desire to safeguard the right of ownership as it was regarded

15. Dickinson v. Goodspeed, 62 Mass. (8 Cush.) 119 (1851). The Dichinsun case vas cited with approval in Wurm v. Allen Cadillac Co., 301 Mass. 413, 418, 17 N.E2d 305, 308 (1938) (lessee not held liable since "the owner himself had na right to enter and could not lawfully authorize the plaintiff to do so").

16. Restatenext, Torts $\$ 329$, comments $a$ and $c$ (1934). But ef. note 23 infra.

17. Restatenent, Torts $\$ 382$ (1934).

18. Id. $\$ \S 383-7$.

19. Id. $\S 384$. Cole v. Willcutt \& Sons Co., 214 MIass. 453, 101 N.E. 995 (1913); Blackstone v. Chelmsford F. Co., 170 Mass. 321, 49 N.E. 635 (1898). Sce Belliveau v. New York Cent. R.R., 321 Mass. 72S, 75 N.E.2d 645 (1947) (railroad has same immunities as owners of tracks over which it has right to run); Gravelle v. New Yorl;, N.H. \& H.R.R., 282 11ass. 262, 1S4 N.E. 717 (1933) (same); Hafey v. Turners Falls Power \& Electric Co., 240 Mass. 155, 133 N.E. 107 (1921) (electric company treated the same as the owner of the proserty over which were strung the wires which caused the accident). But cf. Sarna v. American Bosch Magneto Co, 290 Miass. 340, 195 N.E. 328 (1935), discussed in note 20 infra.

20. See Miudrich v. Standard Oil Co., 153 Ohio St. 31, 90 N.E.2d 859 (1950) (question reserved with regard to invitees; however, the treatment of the facts suggests that invitees do not share the special protection accorded occupiers at least where active negligence is concerned).

In Sarna v. American Bosch Magneto Co., supra note 19, defendant (which dumpad dangerous substance on another's land) was held not to share the owner's immunities towards a licensee on the land, whether defendant was invitee or merely licensee of owner. The court distinguished other Massachusetts cases, supra note 19, where the owner had "invested the defendant with possession of some part of his land," or had let him put some structure there.

21. McPheters v. Loomis, 125 Conn. 526, 532, 7 A.2d 437, 441 (1939). 
under a system of landed estates, ${ }^{22}$ then there seems to be no reason for extending special tenderness beyond the scope required by precedent, or for enlarging the class of defendants exempted from the duty generally owed by all men to use reasonable care towards everyone likely to be hurt by their carelessness. ${ }^{23}$ The point is one on which the cases go both ways. ${ }^{24}$ Some thirty years ago they were "quite evenly divided upon it," but later cases incline the weight of authority towards holding the non-occupier to the duty of reasonable care. ${ }^{25}$

\section{Condition of the Premises}

To those who come on to land without the occupier's permission, or some other right to do so, the occupier still owes a very limited duty with respect

22. See Humphrey v. Twin State Gas \& Electric Co., 100 Vt. 414, 418, 139 Atl. 440, 442 (1927).

23. This reasoning might also apply to adverse possessors prior to the ripening of possession into title. But of. note 16 supra and accompanying text.

On the other hand, it has been urged that to deny business invitees the immunity of the occupier would limit the occupier's beneficial use of the property, since the presence of business invitees (which is of benefit to the occupier) would thereby be burdened and discouraged. Note, 21 MinN. L. REv. 338 (1936). It might also be argued that the valid core of policy behind the immunity, i.e., the encouragement of beneficial exploitation of land, applies to all who are engaged in such beneficial exploitations. This would include many invitees and easement-holders, as well as occupiers.

However, whether these burdens would, in fact, inhibit useful enterprise is very cloubtful. See James \& Dickinson, Accident Proneness and Accident Law, 63 Harv. L. Rev. 769,781 (1950).

24. Note, 14 A.L.R. 1023, 1035 (1921). Compare Guinn v. Delaware \& A. Tcl. Co., 72 N.J.L. 276, 62 At1. 412 (1905) (telephone company owed duty of due care to trespasser), with Robbins v. Minute Tapioca Co., 236 Mass. 387, 128 N.E. 417 (1920) (electric company owed duty only to refrain from wanton and wilful conduct towards trespassers).

25. See cases cited Note, 56 A.L.R. 1021, 1030 (1928). Later cases which deny the immunity are: Langazo v. San Joaquin L. \& P. Corp., 32 Cal. App. 2d 678, 689, 90 P.2d 825, 831 (1939); Wise v. Southern Indiana Gas \& Electric Co., 109 Ind. App. 681, 691, 34 N.E.2d 975, 979 (1941) ; Sarna v. American Bosch Magneto Co., 290 Mass. 340, 195 N.E. 328 (1935) (discussed note 20 supra) ; Baker Utilities Co. v. Hancy, 203 Okla. 91, 93, 218 P.2d 621, 623-4 (1950). See also Prosser, Torts 612-13 (1941); 18 AM. Jur, Electricity $\$ 67$ (1938); 29 C.J.S., Electricity $\$ 43$ (1941).

But cf. Petrak v. Cooke Contracting Co., 329 Mich. 564, 568, 46 N.W.2d 574, 576 (1951). This case also suggests the possibility of distinguishing the above cases on the ground that they involve an inherently dangerous instrumentality (electricity). However, the language in the cases is broad enough to support the general statements appearing in the text. See, e.g., Humphrey v. Twin State Gas \& Electric Co., 100 Vt. 414, 418, 139 Atl. 440, 442 (1927) ("The object of the law being to safeguard and protect the various rights in land, it is obviously going quite far enough to limit the immunity to the one whose rights have been invaded. . . A trespass is an injury to possession; and as it is only he whose possession is disturbed who can sue therefore, so it should be that he, alone, could assert the unlawful invasion when suit is brought by an injured trespasser."); Fitzpatrick v. Penfield, $267 \mathrm{~Pa}$. 564, 109 Atl. 653 (1920) (same notion applied where danger on defendant's land jeopardized trespassers on his neighbor's land). 
to conditions of the premises. If the dangerous condition is a natural one, any such duty would involve the kind of affirmative obligation that the law has traditionally been reluctant to impose. ${ }^{20}$ It is not surprising then that the possessor of land generally owes a trespasser no duty to discover, remedy, or warn of dangerous natural conditions. 27 Perhaps if the possessor sees a trespasser about to encounter extreme danger from such a source, which is known to the possessor and perceptibly not known to the trespasser, there may be a duty of care to warn ${ }^{28}$ (as by shouting). That is about as far as the bystander's duty to a highway traveler would go, if indeed it would go that far. ${ }^{29}$ It could hardly be expected that the law would push this doubtful area of liability further in favor of a trespasser, unless perhaps it came to regard the mere passive ownership of land as an enterprise (because of its potential benefit, its insurability, ${ }^{30}$ and so on ), and this kind of risk as one the enterprise should bear. This seems unlikely.

According to the traditional statement, the possessor's duties toward trespassers were just about as limited when the danger came from a structure or other artificial condition on the land.31 In general there was no duty to dis-

26. See Bonlen, op. cit. stpra note 3 , at 33 at seq.; James, sispra note 1, at 800.09; MeNiece \& Thornton, Affimatize Dutics in Tert, 58 Y.aLe L.J. 1272 (1919).

27. Eldredge, Tort Liability to Trespassirs, 12 TEarp. L.Q. 32 (1937), reprinted in Eldrenge, Modern Tort Problems 163, 187 (1941). Actual decisions to this effect are at least scarce, but the proposition is conceded by all hands. See, c.g., Peters v. Bowman, $115 \mathrm{Cal} .345,47 \mathrm{Pac}$ 113, (1S96) (pond backed on defendant's land by embanliment made by city, and "considered as a natural pond" as to defendant); Bagby v. Kansas City, 338 Mo. 771, 92 S.W.2d 142 (1936) (loose rock in cliff in part of parls not intended for wall: or playground).

Where artificial conditions more or less duplicate natural conditions, some courts similarly deny a duty of care. Anderson v. Reith-Riley Construction Co., 112 Ind. App. 170,44 N.E.2d 184 (1942) (artificial cliff which merely duplicated a natural clifi); Plotzki v. Standard Oil Co, $22 S$ Ind. 51S, 92 N.E.2d 632 (1950) (artificial pond which merely duplicated a natural pond); Zagar v. Union Pacific R.R., 113 Kin. 240, 214 Pac. 107 (1923) (artificial bluff which merely duplicated a natural bluff); Arnold v. St. Louis, 152 M1o. 173, 53 S.W. 900 (1S99) (pond backed onto city street-child slating thereon drowned when ice broke); Atchison T. \& S.F. Ky. v. Powers, 206 Olda 322,243 P.2d 6SS (1952) (general holding on artificial and natural ponds). See p. 165 isfra.

28. Restatesent, ToRts $\$ 337$ cäcut (1934). Cf. Elnange, Modasi Tont PropLEAIS 187 (1941).

29. James, supra note 1, at S03. See also Note, 52 CoL. L. Rev. 631 (1952).

30. Ehrenzweig, Assurance Oblige-A Comparative Study, 15 LAw \& Costzrs. Prok. 445 (1950).

31. See Melendez v. Los Angeles, \& Cal. 2d 741, 6S P.2d 971 (1937); McPheters v. Loomis, 125 Conn. 526, 7 A.2d 437 (1939); Boyer v. Guidicy Marble, Terrazzo \& Tile Co., 246 S.W.2d 742 (Mo. 1952) ; Ehret v. Scarsdale, 269 N.Y. 198, 199 N.E. 56 (1935); Previte v. Wanskunk Co., - R.I. -, 90 A.2d 769 (1952) ; Southern v. Cowan Stone Co., $18 S$ Tenn. 576, 221 S.W.2d 809 (19.9). See also H.ARPEs, TorT $\$ 90$ (1933) (no distinetion made between artificial and natural conditions); Prosses, Torrs $\$ 77$ (1941) (same); 38 Axr. Jur., Negligence $\$ 109$ (1941) (same); 65 C.J.S., Negligence $\$ 24 c$ (1950) (same); Restatentent, Torts $\$ 333$ (1934) (same). 
cover, remedy, or warn of such a danger. Conditions that were pregnant with likelihood of harm and would reek with negligence if such a dity were owed, might be left with impunity as far as trespassers were concerned. ${ }^{\mathrm{g2}}$ This result is not so readily accounted for by the distinction between misfeasance and nonfeasance, although condition of premises cases are often assimilated to passive negligence or nonfeasance. ${ }^{33}$ Here the possessor has engaged in activity by artificially arranging the land for his own purposes. Why does he not, therefore, come under the duty of care to take reasonable precautions to prevent these arrangements from causing foreseeable and unreasonable risk of harm to trespassers? Why is he not subject to the ordinary duty to refrain from negligence? Several reasons have been urged.

It is often said that people are not likely to trespass, so that the possessor of land may disregard their possible presence..$^{34}$ This may be recognized as a variant of the oft-recurring notion that a man may assume lawful conduct on the part of others and need not anticipate wrongdoing. ${ }^{35}$ If this were put forth as a broad generalization of fact to support a rebuttable presumption, it would fit well enough into the framework of negilgence. If the duty of care is created and measured by the probability of harm, then the fact that no one is likely to be within the range of defendant's conduct means that he need not do it carefully, whether he is in the desert, on his own land, or even on a lonely stretch of road. ${ }^{36} \mathrm{But}$ a trespasser's presence is often foreseeable in fact,

32. See, e.g., Richardson v. Whittier, 265 Mass. 478, 164 N.E. 384 (1929) (dirceted verdict for defendant who had left open the guarding gate of an elevator well 26 inches from sidewalk; court declared that plaintiff was unprotected by relevant department of public safety elevator regulations since he was a trespasser); Dehanitz v. St. Paul, 73 Minn. 385, 76 N.W. 48 (1898) (unfenced slough near highway, used for dumping ground, and covered over by thin crust on which weeds had grown; ten-year old child cutting across lots broke through and drowned; held, demurrer to complaint should have been sustained) ; Bottum's Adm'r v. Hawks, 84 Vt. 370, 79 Atl. 858 (1911) (unguarded opening into underground mill race near highway and playground).

33. This was the approach Bohlen took. Bohlen, op. cit. supra note 3 , at 33 et seq. But cf. id. at 182-3. See also authorities cited notes 27 and 31 supra.

34. See Wolfe v. Rehbein, 123 Conn. 110, 113, 193 Atl. 608, 609 (1937); Rahe v. Fidelity-Philadelphia Trust Co., $318 \mathrm{~Pa} .376,378-80,178$ Atl. 467, 467-9 (1935). Sec also BoHLEN, op. cit. supra note 3 , at 61 ; ElDREDGe, op. cit. supra note 28 , at 164 ; Prosser, ToRTS 610 (1941).

35. For a general analysis of this notion see James, Nature of Negligence, 3 UTA11 L. REv. 275, 291-2 (1953).

36. See Brown v. Kendall, 60 Mass. (6 Cush.) 292, 296 (1850) ; Fitzpatrick v. Penfield, $267 \mathrm{~Pa}$. 564, 574-6, 109 Atl. 653, 657 (1920).

The nature of the locality, as it affects the probability of harm, may also affect the question of whether strict liability is to be imposed. See, e.g., Gilbert v. Davidson Con* struction Co., 110 Kan. 298, 203 Pac. 1113 (1922) (whether operation of rock orusher was a nuisance) ; Heeg v. Licht, 80 N.Y. 579, 36 Am. Rep. 654 (1880) (applicability of strict liability for storing of explosives); Kendall v. Johnson, 51 Wash. 477, 99 Pac. 310 (1909) (whether blasting by contractor "in the Cascade Mountains far removed from any human habitation" involved such inherent danger that contractor's employer would be vicarious= ly liable for it). 
and when that is so, the occupier should not be exempted from the obligation of ordinary care by a rule of law founded on a premise of fact shown not to exist in this case. ${ }^{37}$

It is also urged that the duty of care towards trespassers would impose an unreasonable burden on the use of land..$^{38}$ This contention has several aspects. In the first place the duty not to be negligent is only a duty to take reasonable precautions against undue risk of harm. Even if the possessor were to come under the ordinary rule of negligence, therefore, he could always repel the obligation to take any precautions he could show to be unreasonably burdensome. The law of negligence is itself an accommodation to the social need for dangerous enterprise and activity. This at least is the theory. ${ }^{39}$ Yet it may be urged with some reason that however careful a defendant has been, in nearly every case the ingenuity of counsel after the event can suggest some further or alternative precaution that might have avoided injury $:^{30}$ and, since juries are ever ready to find a defendant negligent, ${ }^{\text {11 }}$ this would in practice burden occupiers of land with an infinite series of precautions, or in effect make them insurers against injury caused by the dangerous conditions of their land.42 Something approaching this perhaps obtains broadly in the accident field. The question here is whether or not the use of land ought to be exempted from the treatment accorded to enterprises generally.43 It is submitted that the only reasons for doing so are: (1) the sanctity once attributed to land ownership and the elevation of this value over the lives and limbs of trespassers, particularly in England; and (2) the fact that there are

37. Under the traditional rule, "A landowner may in fact reasonably anticipate an invasion of his property, but in law he is entitled to assume that he will not be interfered with." Guinn v. Delaware \& A. Tel. Co., 72 N.J.L. 276, 278, 62 Atl. 412, 413 (1905). See Fitzpatrick v. Penfield, supra note 36 , wherein the presence of child trespassers on adjoining land was thought likely enough to afford the basis of a landowner's lisbility, although the court thought that the owner of the premises trespassed ugon would not be liable.

38. See, c.g., Bagby v. Kansas City, 338 Mo. 771, 779-\$0, 92 S.WW.2d 142, 147 (1936); Delaware, Lackawana \& W.R.R. v. Reich, 61 N.J.L. 635, 40 Atl. 682 (1898) ; Bottum's Adm'r v. Hawks, 84 Vt 370, 79 Atl. S5S (1911). Also see Smith, Liability of Landercicrs to Children Entering IVithout Pcrmission, 11 Hasv. L. REv. 349, 362 (1898) ("To s3y ... that $B$ must keep his land in safe condition to be trespassed upon ... might in effect amount to a confiscation of his land for the benefit of trespassers.").

39. James, Nature of Negligence, 3 UTaE L. Rev. 275, 279-86 (1953).

40. See Smith, Liability of Landoziners to Children Entering I'ithont Permission:II, 11 HARv. L. REv. 434, 435-9 (1898).

41. See Clark and Shuluan, A Study of Law Adsinistmation ra Comiecticut 30 (1937); James, Funtions of Judge and Jury in Negligente Cases, 58 Yare L.J. 667, $687,(1948)$.

42. Smith, supra note 40 , at 435 .

43. In an interesting discussion of this trend, Ehrenzweig suggests that an enterprise compensate for injuries that might have been foreseen as typical casualties of such enterprise, and that this test should supplant the one which bases liability on foresceability of harm from specific acts. Ehrenzweig, sipra note 30. 
many small homeowners in this country. The first reason is not a good one, though it may well be the actual one.44 As to the second, it may be said that the bulk of these accidents involve industrial or business property, and that the slight risk of the small landowner is readily and reasonably insurable.40

Another reason advanced for the immunities of land occupiers is that the trespasser is a wrongdoer. ${ }^{46}$ Sometimes this is put in the form of contributory negligence $; 4$ and a trespass under the circumstances of a given case may amount to contributory negligence, as where a man walks along a single track railroad trestle. Where this is the case, his contributory negligence ${ }^{48}$ would be a factor to consider under the ordinary rules of negligence quite aside from the trespass. But the trespass is often given an effect over and above that accorded to contributory negligence. . $^{40}$ Moreover, trespassing is not always or even usually negligent. The wrong it entails is the invasion of a property interest, not the subjection of oneself to unreasonable risk of harm. ${ }^{50}$ All in all, this aspect of trespass could not account for the traditional

44. See sources cited note 13 supra.

45. Any one who opposes the current trends in accident law generally will, of course, regard the land occupier's immunities with kindly eye.

46. See, e.g., Salt River Valley Ass'n v. Compton, 40 Ariz. 282, 285, 11 P.2d 839, 840 (1932) ("It would be intolerable that one who would not have been injured save for his own unlawful act may penalize another."). See also Peaslee, Duty to Scen Trespasscrs, 23 Harv. L. Rev. 403, 406 (1914) ("The [reason] most frequently advanced is that the plaintiff cannot by his own wrong impose a duty toward him upon the innocent landowner."). A recent statement of this point of view may be found in Note, 31 TEx. L. REv. 80 (1952).

47. See, e.g., McAllister v. Jung, 112 I1l. App. 138, 147 (1904) ("Such persons are not merely contributors to any injury they may there sustain, but active in inflicting the injuries upon themselves. ..."). See also Prosser, Torts 611 (1941).

48. See James, Contributory Negligence, 62 YALE L.J. 691 (1953).

49. Thus courts have denied recovery to trespassing children too young to be negligent. See Santora v. New York, N.H. \& H.R.R., 211 Mass. 464, 98 N.E. 90 (1912) (child 27 months old); Moore v. Penn. R.R., 99 Pa. 301, 305 (1882) ("The circumstance that the trespasser was a boy . . . cannot affect the application of the rule" [of nonliability to trespassers].).

50. And even in this respect, the "wrong" to property may be an innocent one. Yet, "[a] plaintiff cannot avoid the rule governing trespassers and bare licensees by showing that he was carried upon the property by accident or against his will. The question is primarily one of duty on the defendant's part rather than innocence on the plaintiff's." Trudo v. Lazarus, 116 Vt. 221, 224, 73 A.2d 306, 308 (1950). On the other hand, where the danger is near a highway and plaintiff a highway traveler, his trespass is treated as only "technical" and is overlooked; this may represent an unconscious recognition of the distinction between the kinds of wrong suggested in the text. E.g., Downes v. Silva, 57 R.I. 343, 190 Atl. 42 (1937). See sources cited note 86 infra. Although the courts ${ }^{\prime}$ handling of such cases may be rationalized on the de minimis principle, the traditional rigidity of the property concept of trespass suggests that the courts may be applying a qualitative distinction (i.e., one concerned with whether the kind of wrong has relevance under the negligence concept as opposed to the property concept) rather than a quantitative (i.e., one concerned with the size of the trespass) one in such cases. See, e.g., Gera- 
rule. If his wrong puts the trespasser beyond the pale of a duty of ordinary care, this is because he is treated as something of an outlaw who is not entitled to the benefit of rules requiring humane consideration for people generally. ${ }^{51}$ Perhaps landed gentry did once so regard the poacher in England. ${ }^{52} \mathrm{~A}$ trace of it may still linger in the more emotional aspects of the notion that the useful exploitation of land should not be interfered with. But such an attitude finds little modern acceptance in our law. ${ }^{.3}$ It seems especially inappropriate here in view of the relatively innocent character of many trespasses.

The trespasser's assumption of risk has also been urged as a reason for the possessor's immunities, ${ }^{54}$ but this is rather one way of describing the rule than of accounting for it. ${ }^{55}$ There is no express and often no conscious or voluntary assumption of any risk here. The trespass is usually voluntary, but the risk is imposed by law on the trespasser no matter what his state of mind, or even his capacity. There may be a general feeling that it should be imposed on him, but if so, we are driven back to seek the reason for the feeling. The only thing that "assumption of risk" adds to the discussion is a possible reminder of the fact that mature, conscious trespassers ordinarily do not expect premises to be prepared for their safety.

In sum then, the traditional rule confers on an occupier of land a special privilege to be careless which is quite out of keeping with the development of accident law generally and is no more justifiable here than it would be in the case of any other useful enterprise or activity. As we have suggested, this special privilege is receding; it remains here to trace the current developments of this recession.

gosian v. Union Realty Co., $2 S 9$ Mass. 104, 193 N.E. 726 (1935) (rejecting quantitative test in case involving invasion of property interest).

51. Cf. Rolli v. Converse, 227 Mass. 162, 164, 116 N.E. 507, 503 (1917) ("[A]n unregistered [motor vehicle] is a trespasser . . . and a person riding in an unregistered machine has no rights against other travelers except to be protected from recliless or wilful injury."). This outlaw-trespass-nuisance theory is apparently still the law in Massachusetts. Dean v. Leonard, 323 Mass. 606, 83 N.E.2d 443 (1949). But see Note, 29 B.U.L. REv. 549 (1949). The disfavor with which it is regarded is evident in the unwillingness of the courts to extend the doctrine. Kich v. Finley, 325 Mass. 99, 89 N.E.2d 213 (1949), 30 B.U.L. REv. 266 (1950) (unregistered airplane neither a trespasser nor a nuisance). See James, Statutory Standards and Negligence iss Accident Coses, $11 \mathrm{Ln}$. If Rev. 95, 104 (1950).

52. See sources cited note 13 supra.

53. "This is a severe attitude. Whether we would now adopt it, if the matter were new, is beside the point. We are not disposed to extend its application." Dean v. Leonard, supra note 51, at 609 (unregistered automobile). Thus the fact that defendant trespasses on the land of a third party does not itself make him liable for injuries inflicted on plaintiff. Petrillo v. Kolbay, 116 Conn. 389, 394, 165 Atl. 346, 348 (1933).

54. See McPheters v. Loomis, 125 Conn. 526, 7 A.2d 437 (1939).

55. See James, Assumption of Rish, 61 YaLE L.J. 141 (1952) (general trestment of relationship between assumption of risk and concept of duty). 
The possessor of land may not arrange his premises intentionally so as to cause death or serious bodily harm to a trespasser. ${ }^{60}$ The possessor may of course take some steps to repel a trespass. If he is present he may use force to do so, but only that amount which is reasonably necessary to effect the repulse. ${ }^{57}$ Moreover if the trespass threatens harm to property only-even a theft of property-the possessor would not be privileged to use deadly force even if there is no other way to prevent the trespass. ${ }^{58}$ Where the owner in person would not be privileged to use deadly force, he may not arrange his premises so that such force will be inflicted by mechanical means.60 If

56. 38 AM. JuR., Negligence $\S \S 110,114$ (1941); 65 C.J.S., Negligence $\$ \S 25-6$ (1950) ; Harper, Torts $\$ 88$ (1933); Prosser, Torts $\$ 77$, pp. 613-15 (1941); RestateMENT, TORTS $\$ 79$ (1934); BOHLEN, op. cit. supra note 3, c. 2; Eldredge, Tort Liability to Trespassers, 12 TEMP. L.Q. 32, 33 (1937) ; Smith, Liability of Landozeners to Children Entering Without Permission, 11 HARv. L. Rev. 349, 350 (1898).

57. See, e.g., Escandon v. Pan American Foreign Corp., 88 F.2d 276, 277 (5th Cir. 1937) ("It is elementary that no recovery may be had for an assault and battery to prevent or abate a trespass if no more force be used than is reasonably necessary.") ; Barley v. Ferguson, 209 N.C. 264, 183 S.E. 275 (1936).

The standard plea in defense to a common law action in assault and battery was "molliter manus imposuit" (he laid his hands on [the trespasser] gently).

For a thorough discussion of this subject, see Bohlen \& Burns, The Prizilcge to Protect Property by Dangerous Barriers and Mechanical Devices, 35 Yale L.J. 525 (1926); Harper, Torts $\S 49$ (1933); Miller, Cruminal Law $\$ 69$ (1934); Prosser, Torts $\$ 21$ (1941) ; Restatenent, ToRTs \$\$ 81-2 (1934).

58. See, e.g., McCoy v. Taylor Tire Co., 254 S.W.2d 923, 924 (Ky. 1953); Newcome v. Russell, 133 Ky. 29, 117 S.W. 305 (1909) ; People v. Doud, 223 Mich. 120, 131, 193 N.W. 884, 887-8 (1923) ; cases collected in Note, 25 A.L.R. 508, 525 et seq., 542-7, 560 (1923). See Bohlen \& Burns, supra note 57, at 526 n.3, 540-7; Muler, Criminal Law $\$ 69$ (1934); Prosser, Torts $\$ 21$ (1941); Restatenrent, Torts $\$ \$ 79,85$ comment a (1934). But see Laney v. United States, 294 Fed. 412,415 (D.C. Cir. 1923) ("[O]no may defend his domicile or his property to the extent of taking life, when necessary in defense of his property, or to protect himself or those in his charge from death or bodily injury.").

59. This statement is controversial, and the controversy extends to the use of nondeadly as well as deadly force. The leading statement supporting the text is found in Johnson v. Patterson, 14 Conn. 1, 11 (1840) ("[T]he law will not justify a man in causing injuries by such means [i.e., spring guns, poisoned food, etc.] which he cannot inflict directly, with his own hands."). See State v. Moore, 31 Conn. 479, 482 (1863) ; State v. Childers, 133 Ohio St. 508, 14 N.E.2d 767 (1938); State v. Marfaudille, 48 Wash. 117, 121, 92 Pac. 939, 941 (1907). See also Millek, Criminal Law $\$ 69$ (b) (1934); ReSTATEMENT, TORTS $\$ 85$ and the accompanying comments (1934). But see Bohlen \& Burns, supra note 57 , at 538 ("It is more than doubtful whether it is, as is sometimes supposed, a principle of common law that one may not do indirectly that which he may not do directly."). In preceding passages the authors justified the use of such devices as barbed wire fences on the ground that "the danger that such a fence or device may inflict a bodily harm slightly in excess of that which the owner might inflict, if he were present in person, is counterbalanced by the impracticability of otherwise protecting the property from intrusions, whether harmless or harmful." Id. at 538. In later passages they argue that greater force, applied indirectly through such devices, is justifiable against burglars than would be justifiable if the land occupier were present, on the ground that "there 
he does, he will be liable even to a thief who is injured by such device. ${ }^{\text {a }}$ Statute apart, 1 he may use deadly means, either in person or by device, where that is reasonably necessary to repel an invasion that threatens life or serious bodily harm to the possessor or to someone he is legally entitled to protect, ${ }^{62}$ or threatens the breaking and entering of his dwelling (and perhaps some other buildings) with felonious intent. ${ }^{03}$ But if mechanical

is no reason to protect actually dangerous intruders by restrictions which deprive the householders of the possibility of effective protection"; and "granting ... that the intruder is, in fact, a burglar, there is less reason to be tender of his rights and interests." Id. at $545-6$.

On the other hand, cases may arise where the application of an amount of force, which would be justifiable if the possessor of land were present, would be unjustifiable if the force were applied indirectly through mechanical devices. See, c.g., Grant v. Hass, 31 Tex. Civ. App. 68S, 6946, 75 S.W. 342, 345-6 (1903) (although possessor may be justified in shooting at innccent trespasser if he reasonally believes latter is absut to steal, yet this defense "calls for the presence of the party inflicting the injury ... for his state of mind ... is what gives rise to the occasion to fire the shot, and is what completes the defense."). Sce Allison v. Fiscus, 156 Ohio St. 120, 134, 100 X.E.2d 237, 244 (1951) (dissenting opinion).

60. Hooker v. Miller, 37 Iowa 613 (1873); Allison v. Fiscus, snpra note 59 . Sce also State v. Moore, supra note 59; State v. Mariaudille, supra note 59; Prossen, Turss \& 21 (1941) ; Mrller, Crininal Law $\$ 69$ (1934) ; Note, 21 U. of Cra. L. Rev. 209 (1932).

The cases which seem contra to the statement in the text were rationalized as follows by Bohlen \& Burns, stpra note 57: "This conflict, however, is nut bascd upan any distinction drawn between the privilege to kill or maim to prevent such an entry dircetly and in person, and the privilege to do so indirectly by mechanical devices. It is based upon a difference of view as to the conditions under which the privilege to lill or maim to prevent a felony arises." Id. at 540 . See note 63 ivifro.

61. See, e.g., Mrnw. Stat. ANw. $\$ 616.44$ (1947) (forbidding the setting of any: "spring gun, pistol, rifle or other deadly weapon.").

62. Restatement, Torts $\$ \$ 79, \$ 5$ (1934). This much is generally conecded. Sce sources cited notes 58 supra and 63 infra.

63. See United States v. Gilliam, 25 Fed. Cas. 1319, No. 15,205a (D.C. 1832); State v. Moore, 31 Conn. 479, 482 (1863); cases cited in Notes, 25 A.L.R. 503 (1923), 32 id. 1541 (1924), 34 id. 1488 (1925).

The rationale of decisions justifying the application of deadly force on the sole ground of the prevention of a felony appears fallacious. See, c.g., State v. Barr, 11 Wash. 481, $487,39 \mathrm{Pac}$ 1080, 1082 (1895) ("The reason why the use of such means vas allowed to prevent crimes of that kind in England was that they were there punishable by death. This being so, there was reason for the rule. If one was about to perpetrate a crime for which under the law his life would be forfeited, there was reason in holding that his life might be taken if necessary to prevent his committing it. But in this country few crimes subject the ones who have committed them to the death penalty, and it is only as to those which do that the reason of the rule has any force"). See also Bohlen \& Burns, supro note 57, at 540-1 n.44 ("Whatever may be said as to the justice of permitting the unofficial imposition of the death penalty upon actual felons, it is certainly an extreme penalty to attach to reasonably suspicious conduct to malke the person unfortunate enough to incur suspicion fair game for one who, however reasonably, misinterprets his actions.").

A sounder rule is that "the right of killing to prevent the perpetration of crime depends more upon the character of the crime, and the time and manner of its attempted 
means are chosen, the occupier takes the risk that they will inflict injury under circumstances wherein he would not have been privileged to use deadly force if present, ${ }^{64}$ as where a fireman is injured by a spring gun. Devices that do not threaten serious injury, e.g., barbed wire, may be used to repel trespassers, ${ }^{65}$ except where forbidden by statute. ${ }^{06}$

In the circumstances just discussed, it is often said defendant sets a "trap" for the trespasser; and, where hidden danger is created with the trespasser in mind, the expression is appropriate enough. But danger to a trespasser may be just as great from conditions which are not aimed at the trespasser at all, but created and maintained to serve a useful purpose of the possessor..$^{07}$ Where such a condition is "highly dangerous" (e.g., a high tension electric wire), where it is not likely to be perceived by the trespasser (e.g., concealed by vegetation), and where it is brought home to defendant that trespassers are likely to be exposed to this risk by the frequency of trespass on that part of the land where the danger is, some cases ${ }^{88}$ and the Restatement ${ }^{00}$

perpetration, than upon the degree of punishment attached to it by law, or upon the fact of its being designated in the penal code as a felony or not." Gray v. Combs, $30 \mathrm{Ky}$. (7 Marsh.) 478, 483, 23 Am. Dec. 431, 436 (1832). See also United States v. Gilliam, supra, at 1320 .

64. Grant v. Hass, 31 Tex. Civ. App. 688, 694-6, 75 S.W. 342, 345-7 (1903) ; Restatement, ToRTs $\$ 85$ illustration 2, comment $d$ (1934). See State v. Childers, 133 Ohio St. 508, 518, 14 N.E.2d 767, 771 (1938) ; Prosser, TorTs 135 (1941); Bohlen \& Burns, supra note 57, at 546-7 (wherein the authors urge a different rule but prophesy that the courts will probably follow the rule in the text).

65. Quigley v. Clough, 173 Mass. 429, 53 N.E. 884 (1899) ; Burrill v. Alexander, 75 N.H. 554, 78 Atl. 618 (1910). See also Bohlen \& Burns, stlpra note 57, at 528-36.

66. See, e.g., Conn. Gen. Stat. \$§ 7156-7 (1949) ; Mass. Ann. Laws, c. 86, § 6 (1946).

67. Compare cases cited note 70 infra, zenth Dobbins v. Missouri, K. \& T. Ry., 91 Tex. $60,64,41$ S.W. 62, 64 (1897) (rejection of the analogy of the trap except where condition was "aimed at" the trespasser). See Note, 8 IND. L.J. 508 (1933).

68. The leading case is Clark v. Longview Pubic Service Co., 143 Wash. 319, 255 Pac. 380 (1927). Other decisions looking in the same direction are Cornucopia Gold Mines v. Locken, 150 F.2d 75 (9th Cir. 1945) ; Burnett v. Ft. Worth L.S.P. Co., 117 S.W. 175 (Tex. Civ. App. 1908) ; Meyer v. Menominee \& M.L.T. Co., 151 Wis. 279, 138 N.W. 1008 (1912). Cf. Hobbs v. Geo. W. Blanchard \& Son Co., 74 N.H. 116, 65 Atl. 382 (1906). In the Burnett and Meyer cases the trespassers were young (12 and 14) and they were not trespassers as to defendant. But the reasoning in the opinions did not turn on either of these points.

A trio' of California cases probably also supports the conclusion here. Malloy $v$. Hibernia Sav. \& L. Soc., 3 Cal. Unrep. 76, 21 Pac. 525 (1889); Loftus v. Dehail, 133 Cal. 214, 65 Pac. 379 (1901) ; Blaylock v. Coates, 44 Cal. App. 2d 850, 113 P.2d 256 (1941). In the Malloy case a very young child fell into an unguarded cesspool about 10 feet from the sidewalk. In the Loftus case (which denied liability) the court distinguished the Malloy case by saying that there "the complaint would have been sufficient to have warranted a recovery had an adult been killed under the same circumstances; for the complaint showed a veritable trap,-a cesspool open and unguarded, yet with its surface covered with a layer of deceptive earth to a level with the adjacent land. Into such a trap any one, adult or child, might have walked." In the Blaylock case, a 13 year-old 
impose on the possessor a duty of care to protect such a trespasser (c.g., by a warning) from the danger. Sometimes the analogy of the "trap" is invoked, ${ }^{70}$ but the real basis of liability seems to be the grave danger of very great harm. ${ }^{71}$ The Restatement rule has been used in favor of adults only sparingly, and in extreme cases. ${ }^{72}$ There is here, however, a concept capable of typical common law growth: "Highly dangerous" may become simply "unreasonably dangerous" $;^{73}$ "concealed" may be watered down to that which plaintiff might be expected in fact not to observe $;^{\text {it }}$ and the possessor may come under a duty to inspect if the threatened danger is great enough. ${ }^{7}$

girl was held entitled to recover (though judgment in her favor was reversed on other grounds) when she left the sidewalk to rescue her dog who was stucl: in a nearby oil sump, in which she also got stuck. Liability was sustained "under the general rule that a landowner may not construct or maintain a trap or pitfall into which he las reason to believe that a trespasser will probably fall." $C f$. note $\$ 3$ infru.

Cases looking in a direction opposite to that indicated in the text are Strother v. Pacific Gas \& Electric Co., 94 Cal. App. 2d 525, 211 P.2d 624 (1949); Rudger's Adm'r จ. Union L.H. \& P. Co., 123 S.W. 293 (Ct. App. Ky. 1909).

69. Restatentent, Torts \$ 335 (1934).

70. Cornucopia Gold Mines v. Locken, supra note 68 , at 76 ("Owing to the condition of brush and vegetation surrounding the fallen wire, it virtually constituted a trap for anyone valling or travelling in the Canyon."); Talkingtun v. Mashingten Puwer Co., 96 Wash. 386, 389-90, 165 Pac. 87, \&8 (1917) ("[T]his power line . . w was nevertheless a very dangerous, silent and even deadly agency, and one which did rivt display its dangers and make them so readily discernible as ruming machincry, high places unprotected by railings, or other similarly apparent dangers.").

71. See sources cited notes 111-114 iafra and accompanying text. See suurces cited notes 68-9 sitpra.

72. See cases cited note 68 supra.

73. Note the development which has talien place in the eases dealing with the liability for negligence of a manufactures to a remote vendee or uther third persin with whom the manufacturer had no contractual relationship. Carter v. Yardley \& Co., 319 Mass. 92, 103, 64 N.E.2d 693, 700 (1946) ("The [acceptance of the] dectrine of the McPherson case ... has brought all dangerous things into the same class as the inherently dangerous' things to which the principle already stated has always been applied."). See Anderson v. Linton, 178 F.2d 304 (7th Cir. 1949) ; Brown v. Bigclow, 325 Mass. 4, \&S N.E.2d 542 (1949); Note, 164 A.L.R 569 (1946). See also James, Seope of Duty in Negligence Casis, $47 \mathrm{Nw}$. U. L. Rev. 778, 798-9 (1953).

74. Note the development which has taken place in the cases dealing with the liability of a possessor of land to a licensee for injuries resulting from "concealed perils." In Washington, liability is apparently still confined to "extraordinary concealed perils," Christensen v. Weyerhaeuser Timber Co., 16 Wash. 2d 424, 432, 133 P.2d 797, 800 (1973). In Connecticut, liability has been extended to "dangeruus conditions which the possessor knows of but which he cannot reasonably assume ... the licensee knows of or by reaconable use of his faculties would observe." Lubenow v. Cook, 137 Conn. 611, 614, 79 A.2d $\$ 26,828$ (1951).

75. Such a duty was apparently imposed by the court in Cornucopia Gold Mines v. Locken, 150 F.2d 75, 77 (9th Cir. 1945): "We conclude that where as in this case the owner of such a transmission line wire negligently fails to inspect and repair it and allows it to become in disrepair and sag near and rest upon brush in wild unfenccl mountainous ... country, so that one leaving a nearby road and walking nu:r ur wrer sueh trans- 
But the duty to trespassers will probably always be limited, as it is now, by the fact that while consciously trespassing, they generally do not expect land to be prepared for their safety and realize they must keep a lookout for their own protection. ${ }^{76}$ The occupier, on his side, may reasonably rely on this fact, even if he is subjected to the full duty of care, and all the precautions that may be required of him will be measured in this light. ${ }^{77}$ This would affect the judgment of what is dangerous and what is concealed, the frequency and carefulness of any inspection that might be required, the adequacy of warning, and so on. The man, for instance, who picks his way in the dark between automobiles in a used car lot and falls into an unguarded grease pit, will be unlikely to recover on any foreseeable tort theory. ${ }^{78}$ Perhaps the careful formulation of the Restatement ${ }^{70}$ may be taken as expressing the rule of negligence with special emphasis on the notion that the occupier may expect trespassers to look out sharply for their own safety -an emphasis which courts may use for tighter control of the jury. At any rate, development beyond the somewhat crystallized Restatement rule to the elasticity usually associated with the negligence formula is likely to be hesitant and un-

mission line would likely come in contact with it and be thereby injured, is guilty of reckless conduct and wanton negligence rendering the owner liable for resulting personal injury...." (emphasis added).

See also Weimer v. Westmoreland Water Co., 127 Pa. Super. 201, 193 Atl. 665 (1937), in which defendant was held liable although on the facts of the particular case, the sole cause of the injury was a defective chain, the danger of which could only have been disclosed by an inspection. However, this point was apparently not raised by the defendant in either the lower or higher court. See Eldredge, Tort Liability to Trespassers, 12 Temr. L.Q. 32 (1937). A later Pennsylvania case, Rush v. Plains Twp., 371 Pa. 117, 89 A.2d 200 (1952), is equivocal as to this duty. Here defendant should have known that children often trespassed on the town dump where plaintiff was burned when part of the surface caved in because of subsurface fires. Plaintiff was denied recovery because the danger was "a latent condition of which the defendant did not have any actual knowledge, or constructive notice. ..." Id. at 121, 89 A.2d at 201. (emphasis added). A dissenting judge stoutly maintained that the evidence did show a basis for constructive notice, saying "Everything is latent to one who closes his eyes, but if one chooses to shut off his vision while hurling a dangerous missile, he cannot escape responsibility for the damage done the struck individual by asserting that he did not see him." Id. at 125, 89 A.2d at 203.

76. See p. 153 supra.

77. Note the continuing emphasis on the likelihood that trespassing children will observe dangerous conditions in the "attractive nuisance" cases. See, c.g., Plotzki v. Standard Oil Co., 228 Ind. 518, 92 N.E.2d 632 (1950); Atchison, T. \& S.F. Ry, v. Powers, 206 Okla. 322, 243 P.2d 688 (1952). See Spear v. Wineman, 335 Mich. 287, 290, 55 N.W.2d 833, 834 (1952) (since a business visitor was not required to be on the alert to discover defects, owner was negligent in maintaining them, though he might not have been liable to a licensee for the same defects, since a licensee would have been expected to keep a sharper lookout). Restatenrent, ToRTs $\$ 343$ comment $d$ (1934).

78. Hume v. Hart, 109 Cal. App. 2d 614, 241 P.2d 25 (1952) (plaintiff's appeal in a similar fact situation said by the court to border on the frivolous).

79. Restatenent, TORTS $\$ 335$ (1934). 
even. Development in the past has been most marked in cases involving conditions near highways, trespassing children, and active intervention. It is to these areas which our examination now turns.

\section{Conditions Near Highway's}

The occupier of land owes a duty of care to prevent artificial conditions on his land from being unreasonably dangerous to highway travelers. ${ }^{89}$ Moreover, if he arranges part of his premises so as to lead people to think that they are part of the highway, e.g., by paving part of his land as a continuation of the sidewalk, he comes under a duty of care to keep that part of his land reasonably safe for travelers. ${ }^{81}$ But his duties go further than this. The law recognizes that travelers are likely to stray or be forced inadvertently from the boundaries of the highway, and requires possessors of abutting land to use care to prevent artificial conditions on it from being unreasonably dangerous to those who may foreseeably deviate in this way. ${ }^{\text {s2 }}$ Thus the landowner has a duty not to create or maintain an unguarded excavation so near the highway as to be unreasonably dangerous to highway travel, even though the excavation is entirely on his own land. ${ }^{83}$

Further, the law recognizes that there are many ordinary and expectable incidents of travel along the highways that may involve technical, sometimes even intentional, trespass on neighboring lands. Children, for instance, must be expected to play as they go along the road and this may include straying

80. 65 C.J.S., Negligence $\$ \$ 77-\$$ (1950); Restatenrent, Torts $\$ \$ 364-\$$ (1934).

81. Crogan v. Schiele, 53 Conn. 186, 5 Atl. 673 (18s5); Holmes v. Drew, 151 Mass. 578, 25 N.E. 22 (1890).

82. The cases are collected in Notes, 14 A.L.R. 1397 (1921), 159 A.L.R. 136 (1945); cf. 65 C.J.S., Negligence $\$ 7 \$(1950)$.

83. Sanders v. Reister, 1 Dak, 151, 46 N.W. 6S0 (1875); Becls v. Carter, 6S N.Y. 283 (1877) ; Kelly v. Sabin Estates, 279 App. Div. 348, 109 N.Y.S.2d 747 (Ist Dep't 1952); Rasmus v. Penn. R.R., $164 \mathrm{~Pa}$. Super. 635,67 A.2d 660 (1949). But see AfcIntire v. Roberts, 149 Mass. 450, 22 N.E. 13 (1S\$9) (responsibility on city rather than abutting owner).

In Loftus v. Dehail, $133 \mathrm{Cal}$. 214, $65 \mathrm{Pac} .379$ (1901), no liability was imposed where pit was 30 feet from street and child was pushed into it. The court distinguished the earlier case of Iralloy v. Hibernia Sav. \& L. Soc, 3 Cal. Unrep. 76, 21 Pac. 525 (1889), where a 3 year old child fell into an unguarded cesspool "with a layer of deceptive earth" over it, some 10 feet from the sidewalk, by calling the conditions " 3 veritable trap [into which] any one, adult or child, might have walked." Id. at $218,65 \mathrm{Pac}$ at 380 . The IIalloy case has been cited as one where the victim came onto defendant's land as a normal incident of highway travel. Barlow v. Los Angeles County, 96 Cal. App. 2d 979, 985, 216 P.2d 903, 907 (1950). But if that was the ground of action, it appears only inferentially from the complaint (the case was decided on demurrer). And Malloy may well stand for the broader principle "that a landowner may not construct or maintain a trap or pitfall into which he knows or has reason to believe that a trespasser will probably fall." Blaylock v. Coates, 44 Cal. App. 2d 850, 852, 113 P.2d 256, 257 (1941). In this view of Malloy the proximity of the highway was significant only as showing the likelihood of trespassers, and liability would be imposed without regard to the question whether the plaintiff's entry on defendant's land might be regarded as an incident of legitimate highway travel. See note $6 S$ supra. 
from the road, or touching fences and adjacent buildings with a stick, so that it may be negligence to leave an exposed electric wire inside the recess of a doorway letting onto the sidewalk, even though the wire is entirely within defendant's property. ${ }^{84}$ Again, it is foreseeable that motorists may stop to relieve nature or change a tire, and that in doing so they are likely to seek shelter or shade that may be off the highway. Negligence may be predicated on creating or maintaining a condition unreasonably dangerous to people foreseeably engaged in such ways. ${ }^{85}$

In all these cases the trespass aspect is not made controlling and the courts are apt to use a straight negligence approach. ${ }^{80}$ This means that the duty and its scope depend upon foreseeability of harm under all the circumstances. The proximity of the danger to the highway, the extent and character of travel, the past practices of travelers, the seriousness of the danger and the likelihood that it will be seen and avoided, and the physical surroundings of the danger, would be among the variable factors entitled to consideration in deciding this cardinal question. ${ }^{87}$ And here again they should be regarded in this light and not erected into rigid rules of thumb. ${ }^{88}$

84. E.g., Ruocco v. United Advertising Corp., 98 Conn. 241, 119 Att. 48 (1922); Haywood v. South Hill Mfg. Co., 142 Va. 761, 128 S.E. 362 (1925). Cf. Sedita v. Steinberg, 105 Conn. 1, 134 At1. 243 (1926).

85. Adults have been allowed to recover where they have encountered conditions on a landowner's property because they have strayed inadvertently, or have been forced from the highway, as by an obstruction. See, e.g., Sawicki v. Connecticut Ry. \& Lighting Co, 129 Conn. 626, 30 A.2d 556 (1943) ; Athens E. L. \& P. Co. v. Tanner, 225 S.W. 421 (Tex. Civ. App. 1920); sources cited in notes 81-3 supra. Recovery has been denied where the adult intentionally left the highway. See, e.g., Frankum v. Farlinger, 35 Ga. App. 305, 132 S.E. 923 (1926) (no liability to one "traveling along the road upon a dark night in an automobile, who leaves the automobile and goes uninvited upon the premises, and, at a point 8 or 10 feet from the road, falls into an unguarded well'); Anderson v. Speer, 36 Ga. App. 29, 134 S.E. 811 (1926) (no liability to a lady who fell down an unlighted stairway adjacent to the sidewalk, because she voluntarily and intentionally deviated from the sidewalk, for the purpose of better viewing an attractive show window). But cf. Gibson v. Johnson, 69 Ohio App. 19, 42 N.E.2d 689 (1941) (liability to plaintiff who, in order to allow others to pass, stepped off sidewalk into an unguarded defective water meter box) ; Murray v. McShane, 52 Md. 217, 36 Am. Rep. 367 (1879) (liability imposed where brick fell from the wall of a house and injured plaintiff who had sat down on defendant's door step to fix his shoe).

The intent of the plaintiff should be merely one factor to consider in determining liability, and not an automatic bar to recovery in all cases. See Note, 36 Micr. L. Rev. 159 (1937).

86. See, e.g., Sinclair Texas Pipe Line Co. v. Ross, 175 Okla. 435, 437, 54 P.2d 204, 206 (1935).

87. Crogan v. Shiele, 53 Conn. 186, 5 Atl. 673 (1885). See Norwich v. Breed, 30 Conn. 535, 544-7 (1826) (dangerous character of condition, rather than its exact location, determines the duty). But cf. Hardcastle v. So. Yorkshire Ry., 4 H. \& N. 67, 157 Eng. Rep. 761 (1859); Binks v. So. Yorkshire Ry., 3 B. \& S. 244, 122 Eng. Rep. 92 (1862); Gramlich v. Wurst, $86 \mathrm{~Pa}$. 74, $27 \mathrm{Am}$. Rep. 684 (1878), which are generally cited for the proposition that the deviation must not be substantial.

88. See case cited in note 86 supra. 


\section{Trespassing Children}

Where a duty of care is owed, the likelihood of the presence of children has great bearing on deciding whether or not conduct is reasonable. ${ }^{53}$ But under the older theory here, no duty of care was owed to trespassers and such a duty was not created by the likelihood that children-or anybody else-would trespass. ${ }^{90}$ This meant, for instance, that a landowner might with impunity leave dangerous machinery or other conditions unguarded on his own land even if it adjoined a primary school's playground.01 The dramatic harshness of such a result led to one of the earliest and best known departures from the stricter rule. A leading American case was Siou.r City \& Pacific Railroud Co. v. Stout, ${ }^{92}$ wherein a six year old boy sued for an injury sustained while he was playing with other boys on an unguarded, unlocked turntable maintained by defendant on its own land, in an unfenced open space "about eighty rods from the company's depot, in a hamlet or settlement of one hundred to one hundred and fifty persons," near a road through the depot grounds "and another travelled road nearby." There was evidence that children had played there before, when railroad employees were present; also that an employee had "forbidden them from playing there." The Supreme Court paid very little attention to the trespass aspect of the case, remarking simply that defendant's waiver of. contributory negligence covered also any possible bar to plaintiff based on the wrongfulness of his trespass. The likelihood of presence and of harm was found to be the basis of a duty to use care, and the jury's implied finding of failure to take reasonable precautions was allowed to stand. This reasoning may be termed a straight negligence approach of a lind that is now coming into increasing favor with courts ${ }^{83}$ and commentators; ${ }^{04}$ but it came fifty years too soon to win general judicial acceptance at the time. The opinion failed to grapple with the paramount conceptual difficulty in the case, as the contemporary legal mind would view it, namely the lack of duty to use affirmative care towards any trespasser. ${ }^{95}$ Since there was no such

89. E.g., Terranella v. Union Bldg. \& Const. Co., 3 N.J. 443, 449, 70 A.2d 753, 756 (1950) ("Where, as here, the obligation exists primarily in relation to groups of young children, that in itself is one of the concomitant circumstances to be weighed.").

90. See Friedman v. Snare \& Triest Co., 71 N.J.L. 605, 611-12, 61 Atl. 401, 403 (1905). See cases cited note 97 infra.

91. Bottum's Adm'r v. Hawks, \&4 Vt. 370, 79 Atl. $85 \$$ (1911).

92. 17 Wall. 657 (U.S. 1S73).

93. See, e.g., Wolfe v. Rehbein, 123 Conn. 110, 115-16, 193 Atl. 608, 610 (1937).

94. See, e.g., Green, Landoaner v. Intruder; Intruder a. Losdontver. Basis of Responsibility in Tort, 21 Mrce. L. Rev. 495, 518-19 (1923); Hudson, The Tumblable Cases in the Federal Courts, 36 HaRv. L. Rev. \$26, \$4453 (1923); Restatearent, Tusts $\$ 339$ (1934).

95. See Dobbins v. Missouri, K. \& T. Ky., 91 Tex, 60, 63-4, 41 S.W. 62, 64 (1897). At this time the notion of a "trap" was pretty closely confined to the spring gun and vicious animal type of situation. Sce, c.g., Daniels v. N.Y. \& N.E.R.R., 154 Mass. 349, 352-3, 28 N.E. 2\&3, 284 (1891) ; Dobbins v. Missouri, K. \& T. Ry., supro. 
duty in the first place, the questions whether the wrongfulness of trespass was a bar, and whether there was negligence, never should have been reached.96

Dissatisfaction with the reasoning in the Stout case took two forms. A good many states-including many of the industrial ones-repudiated liability altogether and preserved intact the occupier's immunities. ${ }^{07}$ The impossibility of preventing trespasses of children, without incurring ruinous expense, ${ }^{98}$ the propensity of juries to favor plaintiffs, ${ }^{09}$ and the burden on the useful exploitation of land were all stressed. ${ }^{100}$ The primary duty of keeping children away from dangerous industrial development was thought to lie with their parents. ${ }^{101}$ The more "liberal" courts, on the other hand, sought to justify the result of the Stout case by reasoning they found more palatable, and seized upon the analogy of decisions like Tozemsend v. Wathen, ${ }^{102}$ in which defendant baited traps with stinking meat in order to lure dogs onto his land to their destruction. ${ }^{103}$ These courts reasoned that if the child came onto the land because of an artificial, highly dangerous, unguarded thing certain to attract young children; and if the child was of an age when it would "follow a bait as mechanically as a fish," without appreciation of its danger; then the possessor's act of creating or maintaining such a condition was deemed an "invitation," and the child an invitee to whom the duty of care was owed. ${ }^{104}$ Once this hurdle had been jumped, the concept of negligence

96. Dobbins v. Missouri, K. \& T. Ry., supra note 95 , at 62,41 S.W. at 63.

97. Ibid. See also Savannah, F. \& W. Ry. v. Beavers, 113 Ga. 398, 39 S.E. 82 (1901) ; Daniels v. N.Y. \& N.E.R.R., 154 Mass. 349, 28 N.E. 283 (1891); Ryan v. Towar, 128 Mich. 463, 87 N.W. 644 (1901) ; Frost v. Eastern R.R., 64 N.H. 220, 9 Atl. 790 (1886) ; Walsh v. Fitchburg R.R., 145 N.Y. 301, 39 N.E. 1068 (1895); Paolino v. McKendall, 24 R.I. 432, 53 Atl. 268 (1902) ; Ritz v. City of Wheeling, 45 W. Va. 262, 31 S.E. 993 (1898).

98. See, e.g., Ritz v. City of Wheeling, snipra note 97, at 270, 31 S.E. at 997 ("And where will not the curiosity, the thoughtlessness, and the agile feet of the truant boy carry him?").

99. See Ryan v. Towar, 128 Mich. 463, 470-1, 87 N.W. 644, 646-7 (1901).

100. See cases cited note 97 supra. See Smith, Liability of Landotmers to Children Entering Without Permission; -II, 11 HARv. L. REv. 349, 434 (1898).

101. See Ryan v. Towar, supra note 99, at 479, 87 N.W. at 649-50. See Smith, supra note 100 .

102. 9 East 277, 103 Eng. Rep. 579 (K.B. 1808).

103. Cf. the analogy used by Holmes, J., in United Zinc \& Chemical Co. v. Britt, 258 U.S. 268,275 (1921) ("[K]nowingly to establish and expose, unfenced, to children of an age when they follow a bait as mechanically as a fish, something that is certain to attract them, has the legal effect of an invitation to them although not to an adult."). The analogy was specifically rejected by the New York Court of Appeals in Walsh $\mathrm{v}$. Fitchburg R.R., 145 N.Y. 301, 39 N.E. 1068 (1895) on the ground that "The act of the defendant in [Tozensend] was not done in the prosecution of his immediate and proper business, but, as the court held, was a mere malicious attempt . . . to entice his neighbor's animals upon his property. ..." Id. at 309.

104. Keffe v. Milwaukee \& St. P. Ry., 21 Minn. 207, 211-12, 18 Am. Rep. 393, 395-6 (1875) ("Now, what an express invitation would be to an adult, the temptation of an attractive plaything is to a child of tender years. ... [t] he defendant . . . knew that by 
became relevant. ${ }^{105}$ This became known as the "attractive nuisance" or "turntable" doctrine;106 it made the possessor liable if plaintiff could show both allurement and negligence. ${ }^{107}$ The requirement of allurement proved severe. ${ }^{103}$ Thus liability was denied where a child was killed by swimming on a hot day in a pool, inviting in appearance but poisoned in fact, because he did not see the pool till he was already a trespasser. ${ }^{100}$ The evidence showed that such trespassing in the vicinity was frequent, so that probability of harm was very great, but there was no "invitation."110

The feeling grew, however, that the real basis of the doctrine was not the spurious invitation but the "value of child life to the community" and the great probability of harm to that interest from dangerous conditions of land left exposed beyond the needs of their use; ${ }^{111}$ especially as an increasingly

leaving this turn-table unfastened and unguarded, it was not merely inviting young children to come upon the turn-table, but was holding out an allurement, which, acting upon the natural instincts by which such children are controlled, drew them by thuse instinets into a hidden danger. ...").

105. Ibid. See also, Barrett v. Southern Pacific Co., 91 Cal. 396, 27 Pac. 666 (1891); Kansas Central Ry. v. Fitzimmons, 22 Kan. 686 (1879); Koons v. St. Louis \& Iron Mlountain R.R., 65 MIo. 592 (1877) ; A. \& N.R. Co. v. Bailey, 11 Neb. 332,9 N.W. 50 (1881); Ilwaco Ry. \& Nav. Co. v. Hedrick, 1 Wash. 416, 25 Fac. 335 (1890).

106. It has also been referred to as the "attractive agencies," "attractive instrumentalities," or "torpedo" doctrine. Schock v. Ringling Bros., 5 Wash. 2d 599, 606, 105 P.2d 838, 842 (1940). The cases are collected in Notes, 36 A.L.R. 34 (1925), 39 A.L.R. 486 (1925), 45 A.L.R. 982 (1926), 53 A.L.R. 1344 (1928), 60 A.L.R. 1444 (1939).

107. The allurement requirement was often made double-barrelcd, su as to include both (a) a requirement that the trespasser was induced to come ontu the property as a result of the attractiveness of some object on the property, United Zine \& Chemieal $C_{w}$. v. Britt, 258 U.S. 268 (1922) ; Salt River Valley Ass'n v. Compton, 40 Ariz. 232, 259, 11 P.2d 839, 842 (1932) ; Hayko v. Colo. \& Utah Coal Co., 77 Colo. 143, 146, 235 Pac 373, 374 (1925) ; MicDermott v. Burke, 256 Ill. 401, 407, 100 K.E. 168, 170 (1912); and (b) a requirement that the attractive object be the proximate cause of the injury, Seymour v. Union Stock Yards Co., 224 Ill. 579, 586, 79 N.E. 950, 951 (1906) ; MIeDermott v. Burke, supra at 407,100 N.E. at 170 ; Swartwood's Guardian v. Louisville \& N.R.R, 129 Ky. 247, 254, 111 S.W. 305, 307 (1908).

108. See cases cited note 107 supra.

109. United Zinc \& Chemical Co. v. Britt, 258 U.S. 268 (1922).

110. The pool was located within a vacant, unfenced lot, approximatcly 1000 feet by 1200 feet, immediately adjacent to a city of 10,000 inhabitants. There was no sign or warning of any kind indicating the dangerous character of the pool. There were several paths across the lot which were used by people, generally without objection, as a short cut; a public highway ran within 100 to 120 feet of the pool and a railway track not har away. See Justice Clarke's dissenting opinion on the great probability of harm. Id. at 276.

However Holmes held that "it does not appear that children were in the habit of going to the place [i.e., the pool, not the path]. ... It is suggested that the roads across the place were invitations. A road is not an invitation to leave it elsewhere than at its end." Id. at 276.

111. Bohlen, Mixed Questions of Law and Fact, 72 U. of PA L. Rev. 111, 120 (1924) ; Eldredge, Tort Liability to Trespassers, supra note 75, at 50. Sce Thompson v. Reading Co., $343 \mathrm{~Pa} .585,591-2,23$ A.2d 729, 732 (1942). 
industrial society multiplied both the dangers and the devices which might reduce them. This attitude has led many courts ${ }^{112}$ and the Restatcment ${ }^{113}$ to reject, in the case of children, the premise on which the occupier's specinl immunities rested, i.e., a judgment that full utilization of land required immunity even at the expense of the lives and limbs of people, and to substitute the more flexible test of negligence which would balance these competing interests on a case to case basis. ${ }^{114}$ This has paved the way to reviving the simple and forthright approach in the Stout case. Ironically enough, some of the states which originally rejected "attractive nuisance" have now embraced the broader doctrine espoused by the Restatement, ${ }^{116}$ while some states which accepted the then "liberal" view at an early day, still cling to its harsh vestigial requirement of allurement. ${ }^{116}$

The four requirements of the more modern Restatement view which the plaintiff must satisfy center around unreasonable probability of harm. First, there must be the probability that children will be exposed to the danger. This may be shown by evidence of allurement. ${ }^{117}$ It may also be shown by evidence of repeated former trespasses, ${ }^{118}$ by the proximity of the danger to a highway or to residences, schools, or playgrounds where children are likely

112. See cases cited note 114 infra. The development in Indiana, Illinois, and Wis* consin is sketched in 27 N.Y.U.L. REv. 722 (1952). But see Neal v. Home Builders, Inc., - Ind. -, 111 N.E.2d 280 (1953) (indicating some retreat from position described in 27 N.Y.U.L. REv. 722). See also Banker v. McLaughlin, 146 Tex. 434, 20 S S.W.2d 843 (1948); Thompson v. Reading Co., $343 \mathrm{~Pa} .585,591-2,23$ A.2d 729, 732 (1942).

113. Restatement, Torts $\S 339$ (1934). Comment $f$ is a typical example of what might be termed a straight negligence approach.

114. See, e.g., Wolfe v. Rehbein, 123 Conn. 111, 116, 193 Atl. 608, 610-11 (1937) ("If the presence of children is to be anticipated, the care to be exercised is such as is reasonable having in view the probability that children, because of their youth, will not discover the condition or realize the risk involved in intermeddling in it or in coming within the area made dangerous by it [pile of lumber].") ; Drew v. Lett, 95 Ind. App. 89, 97, 182 N.E. 547, 549 (1932); Wagner v. Kepler, 411 Ill. 368, 104 N.E.2d 231 (1951); Larson v. Equity Coop. Elevator Co., 248 Wisc. 132, 21 N.W.2d 253 (1946).

115. Compare Wolfe v. Rehbein, sipra note 114 (accepts Restatement doctrine), with Wilmot v. McPadden, 79 Conn. 367, 65 Atl. 157 (1906) (rejects attractive nuisance doctrine) ; Compare Larson v. Equity Coop. Elevator Co., supra note 114 (accepts Restatcment doctrine), with Zartner v. George, 156 Wisc. 131, 145 N.W. 971 (1914) (rejects attractive nuisance doctrine).

116. See note 107 supra.

117. See Saxton v. Plum Orchards, Inc., 215 La. 378, 40 So.2d 791 (1949); Green, Landowner v. Intruder; Intruder v. Landowner. Basis of Responsibility in Tort, supra note 4, at 521; Hudson, supra note 94, at 849; see sources cited note 111 supra. But scc Wolfe v. Rehbein, 123 Conn. 111, 116, 193 Atl. 608, 610 (1937) (which, in repeating the former rejection of the attractive nuisance doctrine, uses language that may cast some doubt on the sufficiency of allurement alone to show likelihood of children's presence).

118. Parsons v. Appalachian Electric Power Co., 115 W. Va. 450, 176 S.E. 862 (1934) ; Wagner v. Kepler, 411 I11. 368, 104 N.E.2d 231 (1951) ; cf. Rahe v. Philadelphia Trust Co., $318 \mathrm{~Pa}$. 376, 178 Atl. 467 (1935). 
to be, ${ }^{119}$ by the accessibility of the dangerous condition to children; ${ }^{129}$ or by any other evidence having a rational tendency to indicate a likelihood of children's presence in such a way as to bring that fact home to the occupier.121 Unless plaintiff can show the likelihood of children's presence where the danger was maintained, he cannot recover under this theory. ${ }^{122}$

In addition to the probability of trespass, the dangerous condition of the premises must be produced by man, and either created or maintained by the occupier. ${ }^{123}$ This requirement stems from the law's reluctance to impose purely affirmative obligations on a man. ${ }^{124}$ It is sometimes said that manmade conditions which merely reproduce natural ones stand on the same footing. ${ }^{125}$ But if there is to be exemption here it must obviously rest on a different basis. That basis may often be found in the fact that children are likely to appreciate the risks of natural dangers, such as water, ${ }^{120}$ fire, ${ }^{107}$ or high

119. Long v. Standard Oil Co., 92 Cal. App. 2d 455, 207 P.2d 837 (1949); Strang v. South Jersey Broadcasting Co., 9 N.J. 3S, \&6 A.2d 777 (1952). Cf. Mforris v. City of Britton, 66 S.D. 121, 279 N.W. 531 (1938). But cf. Gotcher v. Lity of Farmersville, 137 Tex. 12, 151 S.W.2d 565 (1941).

120. Thompson v. Reading Co., 343 Pa 585, 23 A.2d 729 (1942); Shemper v. Cleveland, 212 Miss. 113, 54 So.2d 215 (1951).

That the danger is within a building will not necessarily preelude recovery. Brandenberg v. Equity Coop. Exch., 160 Jinn. 162, 199 N.W. 570 (1924) (recovery allowed); Weiner v. Westmoreland Water Co., supra note 75 (same) ; Nichols v. Consolidated Dairies, - Mont. -, 234 P.2d 740 (1952) (same). But cf. Southern Cotton Oil Co. v. Picrie, 145 Ga. 130, SS S.E. 672 (1915) (recovery denied).

121. E.g., Wolfe v. Rehbein, 123 Conn. 111, 193 Atl. 608 (1931) (lumber piled partly on plaintiff's land); Saxton v. Plum Orchards, Inc., 215 La. 378, 40 So.2d 791 (1949) (pool maintained by defendant in residential subdivision it was developing); Rush $\forall$. Plains Twp., $371 \mathrm{~Pa} .117,89$ A.2d 200 (1952) (nature of place, vic., town dump).

122. McPheters v. Loomis, 125 Conn. 526, 7 A.2d 437 (1939); Jennings v. Glen Aiden Coal Co., 369 Pa. 532, 87 A.2d 206 (1952).

123. See note 27 supra and accompanying text.

124. See sources cited note 26 supra.

125. Plotzki v. Standard Oil Co., 228 Ind. App. 170, 92 N.E.2d 632 (19:0), criticizsd in Note, 4 VAND. L. REv. 198 (1950); Anderson v. Reith-Riley Construction Co., 112 Ind. App. 170, 44 N.E.2d 184 (1942); Zagar v. Union Pacific R.R, 113 Kan. 240, 214 Pac. 107 (1923) ; Harper v. Topeka, 92 Kan. 11, 139 Pac. 1018 (1914).

126. E.g., Melendez v. Los Angeles, S Cal. 2d 741, 6S P.2d 971 (1937) (10 year-old boy); Phipps v. Mritze, 116 Colo. 2S\&, 180 P.2d 233 (1947) (9 year-old boy); Massie v. Copeland, 149 Tex. 319, 233 S.W.2d 449 (1950), reversing 22S S.W.2d 960 (1950) (14 year-old boy) (the two opinions should be compared to sharpen appreciation of the underlying issues); Atchison, T. \& S.F. Ry. v. Powers, 206 Okla. 322, 243 P.2d 6SS (1952), and cases cited therein. See Notes, 36 A.L.R. 34, 231 (1925), S A.L.R.2d 1254 (1949). But cf. Moore v. North Chicago Refiners \& Smelters, Inc, 346 IIl. App. 530, 105 N.E.2d 553 (1952) (4 year-old boys); Banker v. ArcLaughlin, $146 \mathrm{Tex}$ 434, $20 \mathrm{~S}$ S.W. $2 \mathrm{~d}$ S43 (1948) (5 year-old boy; distinguished in Massic case supra on difference in ages). Ban?!er evoked much favorable comment. Green, Landouncers' Responsibility to Childrci, 27 Texas L. Rev. 1 (1948); 1 Bayzor L. Ret. 73 (1948); 3 Southwestezir L.J. 78 (1949) ; 26 TEXAS L. REv. 821 (1948).

127. See, e.g., Lentz v. Schuerman Building \& Realty Co., $35 y$ MFo. 103, 220 S.W.2d 
places, ${ }^{128}$ so that these conditions are not highly dangerous to them. But this is not always the case. Some natural conditions have more concealed danger than a turntable,, ${ }^{120}$ and if a landowner reproduces such a "natural trap," liability should not be excluded. ${ }^{130}$ Given affirmative arrangement of the premises, the touchstone of liability should be unreasonable probability of harm. ${ }^{132}$ All other criteria should be used as guides only, and not erected into rigid rules. ${ }^{132}$

Thirdly, the condition must be one which is likely to cause serious injury 'or death to a child ${ }^{133}$ in a way which he is not likely to appreciate and avoid. ${ }^{134}$ This double-barrelled requirement bears on the likelihood of harm and the gravity of the harm if it happens. ${ }^{135}$ The age of the child will affect the likelihood that he will encounter danger and his ability to appreciate and

58 (1.949) (3 year-old boy). But cf. Missouri Pacific R.R. v. Lester, 219 Ark. 413, 242 S.W.2d 714 (1951) (5 year-old boy); Strang v. South Jersey Broadcasting Co.. 9 N.J. 38, 86 A.2d 777 (1952) (6 year-old child).

128. See, e.g., Sanders v. Baird, 195 Ark. 535, 112 S.W.2d 966 (1938); Zagar v. Union Pacific R.R., 113 Kan. 240, 214 Pac. 107 (1923) ; Coon v. Kentucky \& I.T.R.R. 163 Ky. 223, 173 S.W. 325 (1915) ; Harris v. Mentes-Williams Co., 23 N.J. Super. 9, 92 A.2d 498 (1952). But cf. Heitman v. Lake City, 225 Minn. 117, 30 N.W.2d 18 (1947).

129. See, e.g., Smith v. Windsor R. \& C. Co., 78 Colo. 169, 240 Pac. 332 (1925); 82 Colo. 497, 261 Pac. 872 (1927) ; 88 Colo. 422, 298 Pac. 646 (1931) ; 92 Colo. 480, 21 P.2d 116 (1933) (false bank of reservoir); Plotzki v. Standard Oil Co., 228 Ind. 518, 92 N.E.2d 632 (1950) (numerous sharp drops and deep holes in bottom of artificial pool).

130. Banker v. McLaughlin, 146 Tex. 434, 208 S.W.2d 843 (1948). Cf. Long v. Standard Oil Co., 92 Cal. App. 2d 455, 207 P.2d 837 (1949).

131. See Chief Justice Emmert's dissent in Plotzki v. Standard Oil Co., supra note 129 , at 520, 92 N.E.2d at 635 : "The reasoning that there should be no difference, in determining non-liability, between a natural body of water and an artificially created body of water is wholly specious from the standpoint of causation, as well as human experience. The act of God creates a natural body of water, and from common experience we know that society, from the first settlement, accommodates itself and builds with reference to the existing conditions for which no man is responsible. But when man acts affirmatively tho general rule is he must use due care under the circumstances to avoid injuring others." Judge Gilkinson's dissent thoroughly analyzed the relevant legal precedents and concluded that "no matter how exclusive may be the property rights of the appellec to the use of the pond in question, it is the apparent probability of danger to the children of the community, rather than the rights of property of appellee that determines its duty and the measure of care required of it under the situation prevailing." Id. at 538, 92 N.E.2d at 644 .

This approach was frankly adopted in Banker v. McLaughlin, supra note 130, at 438-42, 208 S.W.2d at 846-8. See also Moore v. North Chicago Refiners \& Smelters, Inc., supra note 126; cases cited note 118 supra.

Commentators have advocated this approach for some time. See, c.g., Green, supra note 4, at 514-15; Note, 4 VAND. L. REv. 198 (1950).

132. Cf. Banker v. McLaughlin, supra note 130, at 441, 444, 208 S.W.2d at 847, 849. And see Green, supra note 4, at 517-522; Hudson, supra note 94, at 844-53.

133. Restatement, Torts $\$ 339$, comment $b$ (1934). See note 149 infra.

134. See sources cited notes $136-48$ infra.

135. See James, sitpra note 39 , at 280-3. 
avoid it. ${ }^{136}$ The older the child, the less the danger that many conditions will have for him. ${ }^{137}$ Consequently, the age of foreseeable trespassers is decidedly a factor in determining the negligence of the landowner. ${ }^{133}$ But even adults are likely to encounter some dangers (while trespassing but acting carefully) such as concealed high-tension wires. ${ }^{130}$ No hard and fast rule as to age should therefore be drawn. ${ }^{140}$ There has been a tendency, however, to confine the present doctrine to very young children; seldom has recovery been granted to a child over fourteen. ${ }^{141}$ This may be, in part, a confusion of the issues of duty and contributory negligence $;^{1+2}$ in part, a hangover from

136. "Age is at once a factor which may bear on the likelihosd of the visitor's coming on the land, and on the visitor's capacity to look after himself after he is there." Hudson, supra note 94, at 847.

137. Compare Massie v. Copeland, 149 Tex 319, 233 S.WW.2d 449 (1950), aill: Banker v. MICLaughlin, 146 Tex. 434, 20 S S.W.2d $\$ 43$ (1948) (14 year-old child held, as a matter of law, to appreciate the peril of a pit of water which a 5 year-old child was held unable to appreciate; so there may be duty to latter and not to former). Sce also Giddings v. Superior Oil Co., 106 Cal. App. 2d 607, 612, 235 P.2d 843, \$45 (1951) ("Whst might constitute an attractive nuisance to a 7 year-old child would be immaterial as applied to a 14 year-old high school student.").

Age, of course, is not the only variable; a 6 year-old boy has been capable of appreciating the danger of a 30 -foot fall from the top of a tank. Stimson v. Bartex P.L. Co., 120 Tex. 232, 36 S.W.2d 473 (1931).

138. No liability was imposed in the following cases: Garrett v. Arlansas Power \& Light Co., 218 Ark. 575, 237 S.W.2d 895 (1951) (17 year-old boy); Moseley v. Kunsas City, 170 Kan. 585, 228 P.2d 699 (1951) (16 year-old boy); Kentuchy Utilities Co. v. Earles' Adm'r, 311 Ky. 5, 222 S.W.2d 929 (1949) (14 year-old boy); Keck v. Woodring, 201 Okia. 665, 208 P.2d 1133 (1948) ; Massie v. Copeland, subra note 137 (14 yearold boy).

139. E.g., Clark v. Longview Public Service Co., 143 Wash. 319, 255 Pac. 380 (1927) ; Cornucopia Gold Mines v. Locken, 150 F.2d 75 (9th Cir. 1945).

140. "In a large measure, each case must be determined in this respect, not alone by age, but by the degree of mentality and intelligence possessed by the child, as shown by the evidence, to observe and appreciate the particular danger." AIcKiddy v. Des Moines Electric Co., 202 Iowa 225, 229-30, 206 N.W. 815, 817 (1926). See Clark v. Pacilie Gas \& Electric Co., 118 Cal. App. 344, 5 P.2d 58 (1931); Cicero State Banl: v. Dolese \& Shepard Co., 298 Ill. App. 290, 18 N.E.2d 574 (1939); Biggs v. Consolidated BarbWire Co., $60 \mathrm{Kan} .217,56 \mathrm{Pac}+4$ (1S99); Ekdahl v. Minnesota Utilities Co., 203 Minn. 374, 281 N.W. 517 (1938) ; Schorr v. Minnesota Utilities Co., 203 MLinn. 384, 281 N.W. 523 (1938). See also Prosser, Torts 623-4 (1941); Note, 23 Mins. L. Rav. 241, 242 (1938). But see sources cited note 138 supra.

141. See Notes, 36 A.L.R. 141 (1925), 39 id. at 489 (1925), 45 id. at $98 s$ (1920), 53 id. at 1351 (1928), 60 id. at 1450 (1929), 8 A.L.R.2d 1300 (1949). Cf. Prosser, ToRTs 623 (1941) ("In practice it is seldom that children above the age of twelve have been protected."). The general rule is that children 14 years or older are presumptively outside the class protected by the doctrine. See cases cited note 138 supro.

142. Courts have often derived the "over 14 year-old" rule from the analogy of the test for determining the child's capacity for contributory negligence. But the analogy is misleading. If the real basis of the doctrine presently being discussed is the foreseeability of unreasonable harm involved in the defendant's conduct, see notes 114 and 131 supro, then the discretion of the child should be relevant only to deciding the question 
the now generally discredited requirement of allurement. Older children could hardly be "of an age when they follow a bait as mechanically as a fish."

The inability of trespassing children to appreciate the danger ${ }^{143}$ has great bearing on the issue of negligence. People ustally avoid obvious and appreciated dangers, and others may reasonably assume that they will. Surely, it would be an intolerable burden to require a landowner "to guard every stairway, cellarway, retaining wall, shed, tree and open window on his premises, so that a child cannot climb to a precipitous place and fall off."'144 Yet some 7 dangers may be so great and so likely to be encountered, inadvertently perhaps, that it is not reasonable to assume that the knowing child will avoid them. ${ }^{145}$ Thus it may be negligent to have high-tension wires ${ }^{146}$ or explosives ${ }^{147}$

of whether or not, in the light of that discretion, harm was unreasonably foreseeable. And it is by now a commonplace that a defendant will be required to foresee the negligent conduct of others whenever it is, in fact, foreseeable. Of course, even if the child is held to be within the attractive nuisance doctrine, the question of his contributory negligence, in the light of all relevant circumstances, will have to be decided. But that question is different from the one of whether or not the protection of the attractive nuisance doctrine should be available to him. See Note, 25 KY. L.J. 277 (1937); note 145 infrct.

143. This factor was determinative in Phipps v. Mitze, 116 Colo. 288, 180 P.2d 233 (1947); Esquibel v. Denver, 112 Colo. 546, 151 P.2d 757 (1944); Harriman v. Town of Afton, 225 Iowa 659, 281 N.W. 183 (1938); Bagby v. Kansas City, 338 Mo. 771, 22 S.W.2d 142 (1936). See Restatement, Torts $\$ 339$, comment $c$ (1934). Cf. Vincent $v$. Barnhill, 203 Miss. 740, 34 So.2d 363 (1948) ; Atchison, T. \& S.F. Ry. v. Powers, 206 Okla. 322, 243 P.2d 688 (1952). See also notes 128-34 supra.

144. Kayser v. Lindell, 73 Minn. 123, 126, 75 N.W. 1038, 1039 (1898).

145. Such a situation might arise if a child were pushed into the danger, or if he tried to rescue a playmate who was foreseeably threatened by a dangerous condition for which defendant was responsible. See Pierce v. United Gas \& Electric Co., 161 Cal. 176, 118 Pac. 700 (1911). Cf. Atlanta \& W.P.R.R. v. Green, 246 Fed. 676 (5th Cir. 1917), and Judge Weaver's remarks in Edgington v. Burlington, C.R. \& N. Ry., 116 Iowa 410, 434-5, 90 N.W. 95, 104 (1902).

The question of the child's contributory negligence is a separate problem which must be carefully distinguished from that of the land occupier's duty. See pp. 152, 158, 167 stlpra. Unfortunately the issues are often confused. See note 142 supra. Where contributory negligence bars recovery anyway, the confusion does not affect the result. But in cases in which plaintiff may not be contributorily negligent, it would be important to keep the issues distinct.

146. As in the Pierce and Green cases, supra note 145, and the cases cited note 68 supra. But see Olson v. Ottertail Power Co., 65 F.2d 893 (8th Cir. 1933) (majority directed defendant's verdict because 7 year-old plaintiff appreciated danger of live wires).

147. Courts have generally regarded explosives as within the attractive nuisance doctrine. See, e.g., Mattson v. Minn. \& N.W.R.R., 95 Minn. 477, 104 N.W. 443 (1905); Vills v. City of Cloquet, 119 Minn. 277, 138 N.W. 33 (1912); Verran v. Town of Greeneville, 4 Tenn. App. 422 (1927). They have, however, generally refused to apply the doctrine in cases where the child realized the danger involved. E.g., Hutchens v. Nat. Fircworks Dist. Co., 7 Tenn. App. 575 (1928); Stephens v. Blackwood Lumber Co., 191 N.C. 23, 131 S.E. 314 (1926) ; Luttrell v. Carolina Mineral Co., 220 N.C. 782, 18 S.E.2d 412 (1942). Cf. Buckeye Irrigation Co. v. Askren, 45 Ariz. 566, 46 P.2d 1068 (1935); Missouri Pac. R.R. v. Slatton, 193 Ark. 356, 100 S.W.2d 86 (1936); Vaughan v. In- 
exposed and within easy reach of a place which trespassers are lnown to frequent. ${ }^{148}$

It is often said that the condition must be highly dangerous. ${ }^{140}$ The degree of its danger, of course, bears on negligence. ${ }^{150}$ Requiring a probability of serious harm is simply one way to weight the scales to shield the landowner.151 To the extent that such a formula is used in instructions to the jury, its effect is precatory and imponderable. .152 $^{\text {But }}$ it has also served as an invitation to courts to exercise greater control over juries here than they do in negligence

dustrial Silica Corp., 140 Ohio St. 17, 42 N.E.2d 156 (1942). Many of these cases involve the same confusion between duty and contributory negligence suggested in note 142 supra; in other cases the statements of the requirement are clearly obitcr dicta; in still others the decisions rest on theories of proximate cause which are of questionable validity. See James, supra note 39, at 289-93; James \& Perry, Legal Ca:sse, 60 YaLE L.J. 761 (1951).

Perhaps the courts in some of these cases mitigated the harsh implications of mistalien theory by adding still a further element of confusion: letting a jury find that plaintifi failed to appreciate a danger which he manifestly did appreciate. E.g., Buclzeye Irrigation Co. v. Askren, supra, at 577, 46 P.2d at 1072 ("While the evidence and circumstances indicate the decedent [13 year-old boy] did realize and appreciate the danger to which he was exposing himself, we cannot say that persons of equal intelligence and honesty may not reasonably draw a contrary conclusion, as the court in this case did.").

148. Compare the tendency, found often in the law of torts, to minimize defenses as the probability of injury from defendant's conduct increases. See, c.g., James, Coniributory Negligence, 62 Y ALE L.J. 691 (1953).

149. See Massie v. Copeland, 149 Tex 319, 324-5, 233 S.W.2d 449, 452 (1950); RESTATEMIENT, ToRts $\$ 339$, comment $b$ (1934).

The courts usually speak of refusing to impose liability where the condition is not "inherently dangerous," e.g., Jarvis v. Howard, $310 \mathrm{Ky} .38,219$ S.W.2d 958 (1949) (unrailed ramp); Gear v. General Ins. Co., 263 Wisc. 261, 57 N.W.2d 340 (1953) (autumobile) ; Coffey v. Oscar Mayer \& Co., 252 Wisc 473, 32 N.W.2d 235 (1948) (ice trucls); or where it is not "per se" dangerous, e.g., Midkiff v. Wathins, 52 So.2d 573 (L3. App. 1951) (automobile); Brown v. Rosenfield's, Inc., 42 So.2d 885 (La. App. 1949) (escalitor in department store); Peters v. Town of Ruston, 167 So. 491 (La. App. 1936) (artificial lake with no unusual features); Fitzpatrick v. Rose Donahue Realty Co., 151 Minin. 128, 186 N.W. 141 (1922) (barrel of slaked lime) ; Shock v. Ringling Bros., 5 Wash. 2d 599,105 P.2d \&3\$ (1940) (circus wagon; but unloading it might be a "per se" dangerous condition). Compare Hull v. Gillioz, 344 11o. 1227, 130 S.W.2d 623 (1939) (an objcet may be "inherently dangerous" either because of danger inhering in the instrumentality" itself or in the condition in which it was left; thus very heavy leams piled in unstable way may be attractive nuisance), with Emery v. Thompson, 347 Mo. 494, 148 S.W.2d 479 (1941) (pile of cross ties not inherently dangerous since the danger, if any, arising therefrom would be from the negligent manner in which they vere piled.).

150. See James, supra note 39 , at 2\$2-3.

151. Bauer, The Degree of Danger and the Degree of Diffienliy of Remoral of the Danger as Factors in "Attractiz'c Nuisante" Cases, 18 Mrmin. L. Rev. 523 (1934). See also Chicago, B. \& Q. Ry. v. Krayenbuhl, 65 Neb. $8 \$ 9,91$ N.W. 880 (1902).

152. See James, Functions of Judge and $J_{a r y}$ in Negligcnce Cases, 5S Yare L.J. C67, 680-5 (1949). 
cases generally. They have often done this by making categories of objects and conditions which are not to be classed as "attractive nuisances."163 This amounts to the prescription of fixed standards of conduct in a way that is being progressively abandoned in accident law. ${ }^{154}$ The stronger hold of such standards here is probably a vestigial trace of the landowner's special privileges, not destined to endure long. ${ }^{155}$

It is sometimes said that the condition must be unusual. ${ }^{150}$ If, in fact, it is unusual, this may have some tendency to show that it was more likely to attract, ${ }^{157}$ and that its danger was less likely to be understood. ${ }^{168}$ If the condition is not unusual, that may have some tendency to show that it was not unreasonably dangerous. ${ }^{159}$ But again, this should be treated as simply one of many variable factors to be weighed on the issue of negligence. ${ }^{100} \mathrm{Un}$ doubtedly, many usual conditions will fall short of negligence in particular

153. See cases cited notes 27 (simulated natural conditions), 118 (water cases), 119 (fire cases), 120 (high places), and 148 (not inherently or "per se" dangerous) supro. However, few if any of these categories are as absolutely rigid as the statements in the cases seem to suggest. Compare Peers v. Pierre, 366 Ill. App. 134, 83 N.E.2d 20 (1948) (pond containing sticks with which children were in the habit of "playing boats" held not to be attractive nuisance), with Saxton v. Plum Orchards, Inc., 215 La. 378, 40 So.2d 79 (1949) (pond containing sticks with which children were in the habit of "playing boats" held to be an attractive nuisance). See also annotations cited note 106 supra; 38 AM. JUR., Negligence $\S 150$ (1941) ; 65 C.J.S., Negligence $\S 29(12)$ (1950).

154. Green, supra note 4, at 495-6; James \& Sigerson, Particularising Standards of Conduct in Negligence Trials, 5 VAND. L. Rev. 697, 709-14 (1952).

155. Green, supra note 4 , at 522 .

156. Esquibel v. Denver, 112 Colo. 546, 151. P.2d 757 (1944). That the condition was not unusual was a factor in denying liability in Wood v. Consumers Co., 334 I1l. App. 530, 79 N.E.2d 826 (1948) (pond); Shell Petroleum Corp. v. Beers, 185 Okla. 331, 91 P.2d 777 (1939) (pumping machinery in oil country); Payne v. Utah-Idaho Sugar Co., 62 Utah 598, 221 Pac. 568 (1923) (sugar beet dump); Clark v. Bremerton, 1 Wash.2d 689, 97 P.2d 112 (1939) (kerosene flares to light highway excavations).

157. See cases cited notes 117-122 supra.

158. See, e.g., Wood v. Consumers Co., supra note 156. And see Note, 8 A.L.R.2d $1254,1274-6,1293-6$ (1949).

159. See, e.g., Peters v. Bowman, 115 Cal. 345, 47 Pac. 113 (1896) (pond); Dahl v. Valley Dredging Co., 125 Minn. 90, 145 N.W. 796 (1914) (small quantity of naptha in container); Fitzpatrick v. Rose Donahue Realty Co., 151 Minn. 128, 186 N.W. 141 (1922) (slaked lime); Shell Petroleum Comp. v. Beers, 185 Okla. 331, 91 P.2d 777 (1939) (pumping machinery in oil country).

160. "The owner of a thing dangerous and attractive to children is not always and universally liable for an injury to a child tempted by the attraction. His liability bears a relation to the character of the thing, whether natural or common, or artificial and uncommon, to the comparative ease or difficulty of preventing the danger without destroying or impairing the usefulness of the thing, and in short to the reasonableness and propriety of his own conduct, in view of all surrounding circumstances and conditions." Peters v. Bowman, supra note 159, at 356. See also Hudson, supra note 94, at 852.

On the relevance of what is customary to the issue of due care, see James \& Sigerson, supra note 154, at 709-14 (1952). 
cases as a matter of law, ${ }^{101}$ but there should be no rule of thumb requirement that a condition be unusual. 162

The fourth requirement for recovery is that there must have been a reasonably feasible way to remove the danger. ${ }^{103}$ This of course is a universal requirement in negligence law which balances the practicability and cost to the defendant of effective precautions against the probability and gravity of harm to plaintiff. 164 But here again there has been some excess of caution. The Restatement, for instance, would not allow recovery unless "the utility to the possessor of maintaining the condition [was] slight as compared to the risk to young children involved therein." 105 If this means anything beyond the usual formula, which refuses to require precautions that are unreasonable in the light of foreseeable danger, ${ }^{106}$ then it seems hard to justify. As one

161. See, e.g., Kayser v. Lindell, 73 Minn. 123, 126, 75 N.W. 1038, 1039 (1598) (7foot retaining wall not attractive nuisance). Also see cases eited notes $126-8$ sufro and accompanying text; note 162 infra.

162. This is especially true since "unusual" is not a word of art. Thus what is unusual in one jurisdiction may not be unusual in another jurisdiction. And what is usual at one period may be unusual at another period within the same jurisdiction. E.g., are the ordinary poles used by electric light, telephone, and telegraph companies "unusual" enough to be attractive nuisances? Confrare Salt River Valley Ass'n v. Compton, 40 Ariz. 282, 11 P.2d 839 (1932) (yes), with Tesas-Louisiana Power Co. v. Bihl, 65 S.W.2d 672 (Tex. Civ. App. 1933) (no). Junk yards? Constare Thomss v. Anthony, 261 Ill. 28S, 103 N.E. 974 (1913) (yes), with Kelley v. First Bank \& Trust Co., 256 III. App. 439 (1930) (no).

Recovery has been allowed under the attractive nuisance doctrine in eases involving the following instrumentalities: a sidewalk newsstand, Harrison v. Chicago, 303 III. App. 263, 31 N.E.2d 359 (1941) ; a fire escape, Perrin v. Rainwater, 186 S.C. 181, 195 S.E. 283 (1938) ; block and tackle, Webster v. Ruick Ice Cream Co., 156 Wisc. 576, 146 N.IV. 815 (1914); and a pile of steel girders, Snare \& Triest Co. v. Friedman, 169 Fed. 1 (3d Cir. 1909). But cf. Friedman r. Snare \& Triest Co., 71 N.J.L. C05, 61 Atl. 401 (1005) (recovery denied in state court on same facts). It is difficult to see how these instrumentalities can be held, as a matter of law, to be more unusual than the following instrumentalities to which the attractive nuisance doctrine has been held inapplieable: meat grinding machine, Favaro v. Jacobucci, 239 Ill. App. 583 (1926); cooper's buclets in stone quarry, Callahan Construction Co. v. Hughes, 348 110.1209 , 159 S.W.2d 251 (1941); a parked tractor, Rapczynski v. W. T. Cowan Inc, $138 \mathrm{~Pa}$. Super. 392, 10 A.2d $\$ 10$ (1940); and a pond in which there were 13-inch sticks with which children were in the habit of "playing boats," Peers v. Pierre, 336 III. App. 134, 83 N.E.2d 20 (194S).

If the term "unusual instrumentalities" is to be used, it should mean no more than "instrumentalities which create an unreasonable risk of harm under all the circumstances." See sources cited notes 114, 131, 146-7 and 160 sutru. An analysis of the eases suggests most of them actually hold no more than this.

163. "The contrivance must be ... capable of being rendered safe with ease without destroying its usefulness. .." Morse v. Douglas, 107 Cal. App. 196, 201, $290 \mathrm{Pac}$ 465, 467 (1930). See also 38 Axs. JUR, Negligence $\$ 147$ (1941); 65 C.J.S., Negligence $\$ 29(8)(1950)$.

164. James, supra note 39 , at $280-6$.

165. Restatentent, ToRTs $\$ 339$ (d) (1934) (emphasis added).

166. See Chicago, B. \& Q. Ry. v. Krayenbuhl, 65 Neb. $8 S 9,91$ N.W. 880 (1902); 
author has put it: "To require the removal of a great danger only in those cases in which such removal can be accomplished 'with slight expense and little inconvenience ${ }^{167}$ would seem somewhat extreme, for great dangers may render necessary great care, involving more than slight expense and little inconvenience."168

Inspection is one of the commonest precautions which the duty of care may require a defendant to take for the removal of danger. But, it has been said that the occupier of land owes no duty of inspection to discover conditions dangerous to trespassing children. ${ }^{100}$ Such a rule would, of course, be a logical enough corollary of the notion that landowners owed no duty of care to trespassers. But if the general principles of negligence are to be substituted for the older special immunities, then any exemption from a duty to inspect, as a matter of law in all cases, is either a vestige of the older principle which is out of place under the newer one, or the erection of a fixed standard of conduct that relieves one class of defendants from one of the precautions commonly incidental to the exercise of ordinary care ${ }^{170}$ Here, as elsewhere, in any given case, inspection may not be feasible or may seem uncalled for; or an inspection which would have disclosed the particular condition may be unreasonably burdensome. And under general principles, if the danger was neither known in fact nor discoverable by reasonable inspection, the occupier cannot be held. ${ }^{171}$ There is no reason in logic or policy for extending the exemption further. ${ }^{172}$

Both the attractive nuisance doctrine and the Restatement view have been invoked to impose liability where a trespassing child removes a dangerous thing, e.g., dynamite caps, from defendant's land and someone else is injured off the land by the dangerous instrumentality. ${ }^{173}$ But neither notion should

Fisher v. Burrell, 116 Ore. 317, 241 Pac. 40 (1925) ; Morrison v. Phelps Stone Co., 203 Mo. App. 142, 219 S.W. 393 (1920). See note 160 supra.

167. Bauer, supra note 151, here quotes from Brown v. Chesapeake \& O. Ry., 135 Ky. 798, 807, 123 S.W. 298, 301 (1909).

168. Bauer, supra note 151 , at 538.

169. See, e.g., Eldredge, supra note 75 , at 51-2.

170. See HARPER, LAW OF Torts 176 (1933).

171. Thus, even where the duty to inspect is admittedly owed (e.g., to invitees), liability is not imposed for injuries resulting from a dangerous condition which would not have been disclosed by a reasonably careful inspection even though no such inspection has been made. See Miller v. Hickey, $368 \mathrm{~Pa}$. 317, 324, 81 A.2d 910, 914 (1951). See also American District Tel. Co. v. Kittelson, 179 F.2d 946 (8th Cir. 1950); Lundin v. Shumate's Pharmacy, Inc., 98 Cal. App. 2d 817, 221 P.2d 260 (1950); Gowing v. Henry Field Co., 225 Iowa 729, 281 N.W. 281 (1938); Hartman v. Miller, 143 Pa. Super. 143, 17 A.2d 652 (1940).

172. Perhaps the recent case of Rush v. Plains Twp., $371 \mathrm{~Pa} .117,89$ A.2d 200 (1952), goes no farther than this in exonerating the landowner of a duty of inspection toward child trespassers. In this case the court found no evidence of either knowledge or constructive notice, see note 75 supra, which suggests that defendant might have been under a duty of reasonable care to acquire knowledge.

173. E.g., Lone Star Gas Co. v. Parsons, 159 Okla. 52, 14 P.2d 369 (1932). Cf. Katz v. Helbing, 205 Cal. 629, 271 Pac. 1062 (1928). 
be necessary; their only office is to avoid the occupier's traditional immunity when plaintiff is a trespasser. This immunity is out of place since plaintiff here is not a trespasser. Lacking immunity, defendant owes plaintiff a duty to refrain from conduct involving unreasonable likelihood of harm to him. If the intermeddling by trespassing children is foreseeable, ${ }^{174}$ it is negligent to leave the dangerous thing accessible to them. Such foreseeability also extends the scope of risk to people within the limits to which the danger might foreseeably be carried..$^{775}$ The question of a duty to the trespasser should not arise as such. Yet the lack of that duty is sometimes tied up with the notion that a possessor of land need not anticipate a trespass, and if this artificial limitation on foreseeability is carried over to the present situation, it will stand in the way of a duty to plaintiff. ${ }^{170}$ However, the whole modern tendency in our

Of course such cases also arise in states which reject both the attractive nuisance and Restatement doctrines. See, c.g., Morse v. Buffalo Tank Corp., 280 N.Y. 110, 19 N.E.2d 981 (1939) (no liability since attractive nuisance doctrine rejected in New Yorl;, gasoline is not an "inherently dangerous" material, and the children's actions were not reasonably foreseeable); Kingsland v. Erie Co. Agr. Soc, 298 N.Y. 409, S4 N.E.2d 38 (1949) (liability because "aerial bomb fireworks" are inherently dangerous and the children's trespass was reasonably foreseeable) ; Martino v. Rotundi, $91 \mathrm{~W}$. Va. 4S2, 113 S.E. 760 (1922) (no liability since children's trespass is an intervening cause which prevents the landowner's negligence, if any, from being a proximate cause of the plaintiff's injuries). As to the present status of the attractive nuisance doctrine in West Virginia, see Tiller v. Baisden, 128 W. Va 126, 35 S.E.2d 728 (1945); Beatty, The Attractize Nussance Dottrine in the Virginias, 10 WAsH. \& LeE L. Rev. 20 (1953).

174. See Lone Star Gas Co. v. Parsons, supra note 173, at 57, 14 P.2d at 372.

Although the majority of the court refused to impose liability in the MLorse case, supra note 173, on several grounds, they apparently felt it necessary to add that "the fact that a pail containing dirty gasoline, left to accumulate the drippings of a faucet, would lead boys to steal the pail and throw the contents at a fire already burning in the public street, into which fire would trip a boy as he attempted to run by and join the others, is a chain of events containing so many new and unexpected causes that the result was not "within the range of reasonable expectation." 'Id. at 118, 19 N.E.2d at 9S4. And Lehman, $J$., in his dissenting opinion, $i d$. at 123,19 N.E.2d at 987 , argued that "the test of responsibility for injury caused by an act or neglect is always whether a reasonably prudent person would anticipate that from that particular act or neglect injury to another might follow. Where human intervention by third parties, whether by lawiul or wrongful act, may be foreseen by the prudent, such intervention must be talken into account."

175. "The degree of care required is commensurate with the risk involved, depending upon such circumstances as the 'dangerous character of the material' and its accessibility to others, particularly children whose presence should have been anticipated regardless of whether or not they are trespassers. The issue of proximate cause [should be] left to the jury... . There harmful consequences are brought about by intervening and independent forces, the operation of which might haze becir reasonably foresem, there is no breals in the chain of causation of such character as to relieve the actor from liability." "Kingsland v. Erie Co. Agr. Soc, 298 N.Y. 409, 423-4, S4 N.E.2d 38, 45 (1949). See also James, Scope of Duty in Negligente Cases, 47 Nw. U.L. Rev. 77S. 786-S00 (1953).

176. See Martino v. Rotundi, 91 W. Va. 4\$2, 484-5, 113 S.E. 760,762 (1922).

Even when unreasonable risk of harm is foreseeable, three artificial limitations on liability are sometimes imposed where the harm is calused to someone off the premises by $a$ 
law is to reject the notion that acts must be unforeseeable simply because they are illegal. ${ }^{177}$

\section{Active Intervention}

Courts are far readier to invoke the duty of care and the concept of negligence where they find active conduct than where they find a mere condition of the premises. ${ }^{178}$ Any arrangement of the premises by the occupier may be regarded as affirmative activity. ${ }^{170}$ But there is a difference between building a bridge, then failing to inspect and repair it and to warn of its deteriorated condition, on the one hand, and, on the other, hitting or shooting a trespasser or even running a vehicle against him because of the driver's failure to look out or to warn. ${ }^{180}$ In the first case the affirmative act occurred long before the trespass; in the others there was activity by the occupier after the trespass had commenced. There may be some validity in a distinction based on this matter of relative timing. As Jeremiah Smith put it in a leading article:

"The first case is that of a known, present and immediate clanger, one which is imminent and reasonably certain to result in harm, unless the owner then and there does, or omits to do, some act, the

dangerous instrumentality carried from the premises by a child trespasser. (a) Those states which do not recognize the attractive nuisance doctrine sometimes refuse to impose liability as a result of what is regarded as the compulsion of logic. See, e.g., Morse v. Buffalo Tank Corp., 280 N.Y. 110, 117, 19 N.E.2d 981, 984 (1939) ("If the act of the landowner on his own premises would not render him liable to a trespasser or licensee ... [ [his act can] not be transformed into negligence through [the] trespass and stealing of [his] material and transportation away from the premises."). (b) Those states which do not recognize the attractive nuisance doctrine sometimes refuse to impose liability where the instrumentality taken is not "inherently dangerous." Compare Kingsland v. Erie Co. Agr. Soc., 298 N.Y. 409, 84 N.E.2d 38 (1949) (aerial bomb fireworks inherently dangerous; liability imposed), with Morse v. Buffalo Tank Corp., supra (gasoline not inherently dangerous; no liability). (c) Even a state which accepts the attractive nuisance doctrine may refuse to impose liability when the trespassing child realized the danger involved in the instrumentality carried from the property. See cases cited note 147 supro. All three limitations should be removed.

177. See, e.g., Katz v. Helbing, 205 Cal. 629, 271 Pac. 1062 (1928); Mazzocchi v. Seay, 126 W. Va. 490, 29 S.E.2d 12 (1944) (parents will be held liable for negligence if plaintiff can prove that they should reasonably have foreseen that their $4 \frac{1}{2}$ ycar-old child would injure someone with the air rifle and ammunition they gave him). Sce also James, supra note 39, at 289-93; Note, 22 N.C.L. Rev. 333 (1944).

178. Smith, supra note 38 , at 363-6.

179. See note 131 supra. Cf. Green, supra note 4, at 517-20.

180. "There is a broad difference between the case of a trespasser's meeting with an injury by reason of the dangerous condition of the defendant's premises and that of an injury caused by the defendant's active intervention." Mitchell v. Boston \& M.R.R., 68 N.H. 96, 118, 34 Atl. 674, 677 (1894). See Boglen, op. cit. supra note 3, at 49-52, 174-5, 181-201; Peaslee, Duty to Seen Trespassers, 27 Harv. L. Rev. 403, 411 n.17 (1914). Cf. Eldredge, Tort Liability to Trespassers, 12 Temp. L.Q. 32, 47 (1937). Of course, if the condition is consciously prepared for the trespasser, the significance of the difference disappears. See p. 154-6 supra. 
doing or omitting of which would avoid the danger. In the second case the danger may be said to exist chiefly in anticipation. It depends on the course of future events, upon circumstances as yet unknown and fortuitous. In the first case the duty imposed upon the landowner involves simply a temporary, generally only a momentary, interruption of his user. . . In the second case the duty sought to be established is to guard against future dangers. It must frequently involve permanent changes in the mode of user, sometimes necessitating such expense and trouble as would be practically prohibitive of certain modes of user, and in some cases compelling the abandonment of all profitable use." 181

This is a fair generalization, but it does not operate uniformly. Some dangerous conditions of the premises are plain to be seen by the occupier, very serious, and simple and cheap to remedy: some active operations are complicated so that the burden of constant lookout, for instance, would be a severe one. ${ }^{182}$ The differences which Jeremiah Smith pointed out are differences in degree which vary infinitely with the circumstances. The relative point in time when the occupier's affirmative activity took place is only one among these varying circumstances, and is entitled to great weight in some cases and little in others. ${ }^{183}$ Since the theory of negligence accommodates these differences with a flexibility adapted to such infinite variety, it would seem preferable to employ it whenever unreasonable probability of harm affords the basis for a duty of care without making hard and fast distinctions between condition of premises and active intervention. ${ }^{18 t}$ Here, as in this field generally, the trend is towards that result, but the old classifications have become so much a part of conventional legal reasoning that a liberal result may often be reached more readily by manipulating the older

181. Smith, supra note 38 , at 3645 , quoted with approval in Hobbs v. G. W. Blanchard \& Sons Co., 75 N.H. 73, 75-6, 70 At1. 1082, 1084 (1908).

182. Consider the case of the steam locomotive-until recently so common. The long boiler in front of the cab makes a blind spot along the tracls for as much as 150 fect in front of the locomotive, and virtually prevents the engineer from secing anything to the left for a very long distance ahead. Moreover the exigencies of railreading required the fireman often to be away from his seat, down "on deck" firing; if any effective looliout to the left were to be maintained at such times, that would mean the expense of an extra man in the cab.

183. E.g., in Bottum's Adm'r v. Hawhs, \&4 Vt. 370, 79 Atl. 858 (1911), the defendant knew that an uncovered bulkhead opening into a conduit carrying fast-llowing water was dangerous and attractive to children who commonly resorted to the area for amusement. The bulkhead was located near a main street, and a private school was loated nearby. The court admitted that "this open unguarded bulkhead, located as it was, was a serious menace to the children of the community . . . likely to cause accidents of such dire consequences." Id. at 372, 79 Atl. at 859 . It seems incredible to argue that the duty to cover or guard the bulkhead would have involved "such expense and trouble as would be practically prohibitive of certain modes of user." Tet the court refused liability; it found "a heavy moral obligation ... to cover or guard it" but no legal duty to prevent disaster. Ibid.

184. See note 131 supra. See also Green, supra note 4, at 517-20. 
concepts than by rejecting them. This is particularly true in borderline situations where defendant's conduct may, without too much violence to logic, be regarded as intervention. ${ }^{185}$

In most of the cases heretofore discussed, it was assumed that the condition of the premises and the act that caused it both antedated the trespass. Where they do not do so, borderline situations are presented. After a trespasser is known to be in the storeroom, an elevator may be moved without closing the gate. Few courts would hesitate to call the leaving of the unguarded shaft active intervention, though it simply changes a condition of the premises. ${ }^{180}$ A closer case is presented where the condition of the premises is changed before this visit of the trespasser (or before it becomes known) but after the possessor knows facts that render the trespass likely. To be sure the danger in such a case, as Smith put it, "depends" in part "on the course of future events, upon circumstances as yet unknown and fortuitous." Yet the known facts point up the danger a great deal more than would the vague realization that people do occasionally trespass almost everywhere. Where the trespass is likely enough and the facts indicating that likelihood have been brought home to the occupier, courts are becoming increasingly willing to treat a change in the condition of the premises as active intervention. ${ }^{187}$

There are other borderline situations in which courts are becoming increasingly willing to characterize equivocal conduct as misfeasance rather than nonfeasance. In 1897, the New Hampshire Court declared that:

"Danger from machinery in motion in the ordinary course of business cannot be distinguished from that arising from a well, pit, open scuttle, or other stationary object. The movement of the works is part of the regular and normal condition of the premises."188

Thirty years later the same court was willing to regard the failure to stop moving machinery as active misconduct towards a seen trespasser. ${ }^{180}$ It may

185. See McCaffrey v. Concord Electric Co., 80 N.H. 45, 49, 114 Atl. 395,397 (1921) (dissenting opinion).

186. Thus, in Hobbs v. G. W. Blanchard \& Sons Co., 74 N.H. 116, 65 Atl. 382 (1906), defendant's placing dynamite where a child trespasser, whose presence was known, could come in contact with it, was regarded as active intervention.

187. Hobbs v. G. W. Blanchard \& Sons Co., supra note 186; Strang v. South Jerscy Broadcasting Co., 9 N.J. 38, 86 A.2d 777 (1951) ; cf. Lowery v. Walker, [1911] A.C. 10. See also Restatement, Torts $\$ \$ 334-7$ (1934).

Courts have long imposed a duty on occupiers of land which licensees are accustomed to cross, to guard against injuries in consequence of changes in the condition of the premises. See, e.g., Notes, 13 L.R.A. (N.S.) 1126 (1908) ; 20 A.L.R. 202 (1922). And courts have often been ready enough to find that a "trespasser" was a "licensec," whenever that was thought to be the only way of raising a duty of care towards trespassers whose presence was exceedingly likely. See Eldredge, supro note 180, at 34-8. Sce also pp. 180-2 infra.

188. Buch v. Amory Mfg. Co., 69 N.H. 257, 262, 44 Atl. 809, 811 (1898).

189. Castonguay v. Acme Knitting Machine \& Needle Co., 83 N.H. 1, 136 Atl. 702 (1927). See Restatenent, Torts $\$ 338$ (1934). 
also be active misconduct to direct a trespasser to take a dangerous route without warning him of lurking dangers in the premises. ${ }^{100}$

Given active intervention, the question then arises what the occupier's duties are with respect to this intervention. A good many of the earlier cases imposed no duty on the occupier except to refrain from intentional injury. Probably all states, however, have expanded this to include at least a duty to refrain from wanton or wilful misconduct towards a trespasser whose presence is known. ${ }^{191}$ Some states have stopped at this point, ${ }^{102}$ but many of those which purport to do so have added a gloss that to be actively negligent in the presence of a perceived trespasser amounts to wantonness. ${ }^{103}$ This is only a more or less indirect way of requiring the occupier to conduct himself with ordinary care towards a trespasser once the latter's presence has become known. ${ }^{194}$ Under one form or another, this is in substance the rule in the vast majority of American jurisdictions. ${ }^{195}$

Under this rule the presence of the trespasser becomes "perceived" if defendant actually knows that a person or people are present, whether or not he recognizes that plaintiff is a trespasser. ${ }^{180}$ Thus if defendant sees a crowd of people, the duty of care is owed to all of them, as pcople, whether a trespasser is among them or not. ${ }^{197}$ Moreover, if defendant perceives facts or

190. Skladzien v. Sutherland Building \& Construction Co., 101 Conn 340, 125 Atl. 614 (1924). But $c f$. Lackat v. Lutz, $94 \mathrm{Ky} .287,22$ S.W. 218 (1S93), showing how this situation can be complicated by problems of scope of authority and contributory negligence.

191. See Bohlen, Studies in the Law of Torts $164 \mathrm{n} .15$ (1926).

192. E.g., Nashville, C. \& St. L. Ry. v. Priest, 117 Ga. 767, 771-2, 45 S.E. 35, 37 (1903); McIntyre v. Converse, 238 Mass. 592, 594, 131 N.E. 198, 199 (1921). See BoHLEN, op. cit. supra note 191, at 165 ; Green, supra note 4, at 503; Peaslee, stpra note 180 , at 411 ; Note, 30 Yale L.J. 201 (1920).

193. E.g., Reagan v. Reading Co., 126 Pa. Super. 175, 179, 190 Atl. 412,414 (1937); Huff v. Chesapeake \& Ohio Ry., 48 W. Va. 45, 4S, 35 S.E. 866,867 (1900) ("The only" duty the company owed him was not to vantonly or wilfully injure him. Had its employees seen him in time to save him, it would have been their duty to use ordinary care do to so."). See also BoHlen, op. cit. supra note 191, at 167-8; Peaslee, suspro note 189, at 411 .

194. See Eldredge, supra note 180 , at 43 . It should be noted that liability may be imposed under the "wanton or wilful" formula for conduct which is merely inadvertent or the result of nervousness. See analysis of the intent factor in Peaslee, sispra note 180, at $412-16$.

195. See, e.g., BoHLEN, op. cit. supra note 191, at 164-70; Eldredge, supra note 180; Green, supra note 4, at 503; Peaslee, sipra note 1S0; Restatessent, Torrs $\$ 336$ (1934).

Most courts have discarded the "vilful or wanton" formula entirely and have clearly" stated that a duty of due care is owed to perceived trespassers. See, c.g., Herricl: v. Wiwon, 121 Mich. 384, 388, S0 N.W. 117, 118, 81 N.W. 333 (1899); 38 Ax. Jur, Negligence $\S 111$ (1941); 65 C.J.S., Negligence $\$ 24$ (i) (1950).

196. Cleveland-Cliffs Iron Co. v. Metzner, 150 F.2d 206 (6th Cir. 1945); Herricls v. Wixon, supra note 195; cf. Carney v. Concord St. Ry., 72 N.H. 364, 57 Atl. 218 (1903).

197. Cf. Restatement, Torts $\$ 336$, comment $c$ (1934) ("The gossessor's duty to exercise reasonable care in conducting his activities so as to avoid causing bodily harm 
objects which strongly suggest the presence of human beings, e.g., an object on the track which might be a man or a pile of clothes, he is bound to regulate his dangerous activities with that likelihood in view. ${ }^{108}$ Proof that defenclant, or its employees, saw the trespasser may be made circumstantially, even over a direct denial. ${ }^{190}$ Thus it may be shown that defendant responded to plaintiff's presence, e.g., by taking an inadequate precaution to avoid him ; ${ }^{200}$ that plaintiff was in plain sight and clearly visible to one who was looking carefully ahead, as defendant said he was, and so on. But the quest here is for actual knowledge, and the chance to see is relevant only to the extent that it indicates defendant did in fact see. ${ }^{201}$

Where the trespasser's presence is not perceived, the cases take one of three attitudes. Some courts absolve the occupier of any duty towards the trespasser, even with respect to affirmative activities. ${ }^{202}$ This attitude was once quite common, but has steadily been losing ground. ${ }^{203}$ At the other extreme, a very few courts have imposed on the occupier whose activities are highly dangerous, e.g., railroading, the duty of care towards trespassers at any place which is exposed to the activity. ${ }^{204}$ Taking a middle position, the

to a trespasser whose presence is known to him, is based upon his lnowledge of the presence of the trespasser as a man and not as a trespasser.").

198. Cleveland-Cliffs Iron Co. v. Metzner, 150 F.2d 206, 208 (6th Cir. 1945); REstatenent, Torts $\$ 336$, comment $b$ (1934); cf. Frederick v. Philadelphia R. T. Co., 337 Pa. 136, 10 A.2d 576 (1940). But cf. Sorey v. Yazoo \& M.V.R.R., 17 La. App. 538, 136 So. 155 (1931) ; Kansas, Okla. \& Gulf Ry. v. Wickliffe, 201 Okla. 129, 202 P.2d 423 (1948). See also Note, 70 A.L.R. 1116 (1931).

In this connection, it should be remembered that "activities" may include a change in the condition of the premise, a continuing movement of machinery, or conduct likcly to lead a trespasser to encounter a dangerous condition of the premises.

199. See, e.g., Moore v. Kurn, 108 F.2d 906 (10th Cir. 1940); Arnold v. Owens, 78 F.2d 495 (4th Cir. 1935); Grover v. Webster City, 222 Iowa 849, 270 N.W. 329 (1936).

200. See, e.g., Carney v. Concord St. Ry., 72 N.H. 364, 57 Atl. 218 (1903) (ringing of bell).

201. See, e.g., Central of Georgia Ry. v. Sharpe, 83 Ga. App. 12, 19, 62 S.E.2d 427, 432 (1950); Woodward Iron Co. v. Goolsby, 242 Ala. 327, 6 So.2d 11 (1942); Jackson v. Penn. R.R., 176 Md. 1, 3 A.2d 719 (1939); Davies v. Delaware, L. \& W.R.R., 370 Pa. 180,87 A.2d 183 (1952).

The statement in the text refers to an attempt to base liability on the fact that the trespasser was seen. It is not meant to suggest that liability may be predicated only on such a basis. See, e.g., Schmidt v. Michigan Coal \& Mining Co., 159 Mich. 308, 311-12, 123 N.W. 1122, 1123 (1909) ("The weight of authority would appear to be that after the owner of premises is aware of the presence of a trespasser or licensee, or if in the exercise of ordinary care he should know of their presence, he is bound to use ordinary care to prevent injury to them arising from active negligence."). See also Carlson $v$. Conn. Co., 94 Conn. 131, 108 Atl. 531 (1919) ; Polston v. S. S. Kresge Co., 324 Mich. 575, 37 N.W.2d 638 (1949); Brown v. Boston \& M.R.R., 73 N.H. 568, 64 Atl. 194 (1906). Cf. Note, 50 Mrch. L. Rev. 617 (1952).

202. E.g., Santora v. New York, N.H. \& H.R.R., 211 Mass. 464, 98 N.E. 90 (1912).

203. Cf. Eldredge, supra note 180, at 44-5. See cases cited note 201 supra.

204. See, e.g., Texas \& P. Ry. v. Watkins, 88 Tex. 20, 24, 29 S.W. 232, 233 (1895); Missouri, K. \& T. Ry. v. Hammer, 34 Tex. Civ. App. 354, 78 S.W. 708 (1904); Tillman 
Restatement 205 and a majority of courts impose such a duty where, and only where, the likelihood of trespass at some particular point, or limited locality, on defendant's premises is considerable.200 Where, for instance trespassers have beaten a path across railroad tracks near a village, the railroad crews must use reasonable care, e.g., by lookout, warning, and the like, in operating trains at that point. ${ }^{207}$ Some courts have tried to work out rules to govern both the degree of concentration and extent of trespassing which must exist before they will apply the present rule. ${ }^{208}$ But here again, as in this field generally, it seems better to proceed on a case to case basis, applying the guiding principle of unreasonable danger under all the circumstances, rather than attempting to erect a rigid rule from one or another of the circumstances. ${ }^{209}$

v. Public Belt R. R. Comm., 42 So.2d SSS (La. App. 1949); Thompson v. Carley, 140 F.2d 656 (Sth Cir. 1944) (duty imposed by Arkansas statute); Gordon v. Tenn. Cent. Ry., 167 Tenn. 302, 69 S.W.2d 611 (1934) (same: Tennessee statute). The rule is rejected in a majority of jurisdictions. See Note, 22 Sт. Joвw's L. Rew. 118, 1234 (1947).

205. RestaTENIENT, TORTS $\$ 334$ (1934).

206. See, e.g., Carison v. Conn. Co., 94 Conn. 131, 10 At1. 531 (1919); Tice v. Central of Georgia R.R., 25 Ga. App. 346, 103 S.E. 262 (1920); Arrowood v. So. Car. \& G. Extension R.R., 126 N.C. 629, 36 S.E. 151 (1900) ; Carter v. Seaboard Air Line R.R, 114 S.C. 517,104 S.E. 186 (1950); Missouri, K. \& T. Ry. v. Wolf, 76 Olda. 195, 184 Pac. 765 (1919); Johnson v. Lake Superior Terminal \& Transfer Co., \&6 Wise. 64, 56 N.W. 161 (1893). Recent cases are collected in Note, 167 A.L.R. 1253 (1947).

If one compares the facts in these cases with the facts in those cited note 204 supro, it is not at all clear that the difference between this rule and the preceding one is as great as much of the language suggests.

207. See, e.g., Louisville \& N.R.R. v. Sullivan, 244 Ala. 485, 13 So.2d 877 (1943); Bullard v. Southern R.K., 116 Ga. 644, 43 S.E. 39 (1902) ; Clampit v. Chieago, St. P. \& K.C.R.R., \&4 Iowa 71, 50 N.W. 673 (1891) ; Louisville \& N.R.R. v. MicNary's Adm'r, 128 Ky. 408, 108 S.IW. S9S (190S); Note, 167 A.L.R. 1253 (1947).

208. This is especially true in Kentuchy. See, e.g., Louisville \& N.R.R. v. Jones, $297 \mathrm{Ky} .523,180$ S.W.2d 555 (1944) (use of railroad track by fewer than 150 persons daily does not constitute them licensees to whom the operators of trains would owe a lookout duty and the exercise of other precautionary measures for their safety); Deitz v. Cincinnati, N.O. \& T.P.R.R., 296 Ky. 279, 176 S.W.2d 699 (1943) (use of eressing by only 75 persons daily did not impose duty of lookout and varning); Chesapealse \& Ohio Ry. v. Nipp, $125 \mathrm{Ky} .49,100$ S.W. 246 (1907) (duty to lookout and warn will not be extended to rural communities although footpaths crossing track may be used by a large number of persons each day).

209. The trespassing may be concentrated at certain times, as well as at certain places, and if so the duty of care will vary with this circumstance also. Thus if trespassing is extensive only during the day, it may be reasonable to omit warnings or lookout at night. See Louisville \& N.R.R. v. Smith's Adm'r, 186 Ky. 32, 216 S.W. 1063 (1919); Louisville \& N.R.R. v. Welsh, $272 \mathrm{Ky} .120,113$ S.W.2d 879 (1938).

Foreseeable trespassing may be done only in a certain manner, e.g., walking, so that reasonable care does not require the sharper lookout needed to see a man lying down on the track Iouisville \& N.R.R. v. Smith's Adm'r, stpra. But ef. Carlson v. Conn. Co., 94 Conn 131, 108 Atl. 531 (1919) (liability to drunk sleeping on trolley track since his presence in that condition should have been anticipated); Murphy v. Wabash R.R., 223 Mo. 56, 128 S.W. 481 (1910) (negligence may be predicated on failure to see drunls asleep on track at point where persons often crossed track). 
The majority rule has sometimes been rationalized by calling frequent trespassers in limited areas "licensees." 210 This brings us to a discussion of the device of reclassifying trespassers, and thereby bringing them within the protection of the duty of ordinary care under certain circumstances.

\section{Reclassification of Trespassers}

The category of technical trespasser is a wide one. It inclucles the burglar, but it also includes the man or child who short-cuts across vacant land without any good reason to suppose that he has the landowner's permission. So far as the duty of care went, however, the conventional rule took little, ${ }^{211}$ if any, account of these differences. A trespasser was simply a trespasser, and such duty was not owed to him. From the rigidity of this concept, one path of judicial escape has lain in a reclassification of trespassers.

Reclassification has taken one of two forms. To a very limited extent it has meant a frank recognition of differences among trespassers, and a willingness to prescribe different duties as owed to different sub-classifications. ${ }^{212}$ Perhaps the leading case is Lowery $v$. Walker, ${ }^{213}$ wherein the House of Lords recognized that if the public persisted in using a short-cut over private land after the owner's remonstrance-which, however, he was not willing to implement by legal action-they might be owed certain duties that ordinary trespassers might not be. ${ }^{214}$ Such persons have been called "tolerated intruders."215 To the extent that this new classification stresses frequency or likelihood of presence, rather than the extent of toleration or acquiescence by the landowner, ${ }^{216}$ it tends to reflect the application of general negligence principles in this area.

210. See, e.g., Louisville \& N.R.R. v. Jones, 297 Ky. 528, 180 S.W.2d 555 (1944); Louisville \& N.R.R. v. Welsh, supra note 209; Chesapeake \& Ohio Ry. v. Nipp, $125 \mathrm{Ky}$, 49, 100 S.W. 246 (1907). See also Chicago G.W.R.R. v. Beecher, 150 F.2d 394 (8th Cir. 1.945) ; Clampit v. Chicago, St. P. \& K.C.R.R., 84 Iowa 71, 50 N.W. 673 (1891) ; Craig v. Ft. Worth \& D.C.R.R., 185 S.W. 944, 948 (Tex. Civ. App. 1916); Delaney v. Milwaukee St. P.R.R., 33 Wisc. 67 (1873).

211. Dangerous acts or conditions intended to repel trespassers might be justified or not, depending on the motive and character of the trespass. See pp. 154-6 supra.

212. For the use of this approach in reclassifying social guests, see Scheibel v. Lipton, 156 Ohio St. 308, 102 N.E.2d 453 (1951).

213. [1911] A.C. 10 (H.L.).

214. The duty owed in that case was simply not to add a concealed peril to the premises (viz., a vicious, unruly horse) without warning. Many courts in America today would require no special reclassification of plaintiff to find such a duty to him. RESTATEMENT, TORTs $\$ \$ 335-6$ (1934); see note 198 supra. But the House of Lords felt that this reclassification relieved it from deciding whether such a duty was owed to a trespasser, a question which it thought to be a substantial and doubtful one. Cf. Davis v. Chicago \& N.W.R.R., 58 Wisc. 646, 17 N.W. 406 (1883).

215. See Bohlen, Duty of a Landowner to Those Entering His Premises of Their Own Right, 69 U. of PA. L. Rev. 142, 248 et seq. (1921) ("tolerated trespasser"); Harper, Law of Torts $\$ 92$ (1933) ; Prosser, Torts 616, 617 (1941).

216. Bohlen, supra note 215, at 251. See also, Ahnefeld v. Wabash R.R., 212 Mo. 280, 111 S.W. 95 (1908) ; Chesapeake \& O. Ry. v. Rodgers, 100 Va. 324, 41 S.E. 732 
More often this reclassification has involved a continued formal acceptance of the old categories, but with the transfer of a class of trespassers to a more favored group. This has been done in some situations where the probability of harm from defendant's conduct is generally so great that courts are shoclied by the practical implications of strict application of the traditional classification. ${ }^{217}$ This process results in fictions. The reclassification of the child trespasser as an "invitee" under the attractive nuisance doctrine is one example. The calling of frequent trespassers "licensees" is another. To the pragmatist, fictions as such are not necessarily bad. They are often benign in their effects and mark periods of transition to new rules better adapted to changing circumstances. Possibly, fictions do this in ways that are, for subtle reasons of social psychology, easier for people to takie.

But fictions have this danger: They distort the transitional process and often lead to inquiries that have no relevance in terms of vital policy, and to results that are capricious and unjust in such terms. If it be assumed here, for instance, that the vital policy is one of imposing liability for harm on unreasonably dangerous conduct, then neither invitation nor license, but the probability of presence of trespassers and of harm to them is the gist of the matter. If the fictions of "invitation" or "permission" were involed whenever the likelihood of a trespasser's presence was great enough, ${ }^{218}$ then the fictions would not impede the practical operation of the rule, however disingenuous and distasteful the fictions might be to people who have a certain intellectual temperament. But the trouble is that these particular fictions invite misunderstanding, because they have current associations and meanings that are not the same as probability of presence, which may exist despite the most pointed lack of invitation or permission. It is this sort of thing that led to the requirement of allurement as a condition of attractive nuisance. Similarly, in cases of frequent localized trespassing the fiction of "license" has occasionally led litigants and courts onto the false scent of permission or acquiescence. $^{219}$

(1902) ; Green, Landowmer \%. Intruder; Intruder : Lasdociner. Basis of Responsibility in Tort, 21 Mich. L. Rev. 495 (1923) ; Eldredge, Tort Liability to Trespussers, 12 Tearp. L.Q. 32 (1937).

217. Cases involving injury by railroad operations to persons using a frequented path across or along the tracks are collected in Note, 167 A.L.R. 1253 (1947). Cases involving a change in the condition of the premises which threaten users of frequented paths, hallways and the like, are collected in Note, 20 A.L.R. 202 (1922). See also Davis v. Chicago \& N.IW.R.R., 58 Wisc. 646, 17 N.W. 406 (18S3).

218. See, e.g., Louisville \& N.R.R. v. Smith's Adm'r, 186 Ky. 32, 37, 216 S.W. 1063, 1065 (1919) ("Whether a person is a trespasser or a licensee depends upon the number of persons using the track at any given point.").

219. Cases almost without number, in requiring a railroad to use care towards parsons using a frequented path across or along the tracls, mention the railroad's acguicscence in that use, as well as the cxtent of the use, as a basis for the duty. Sce, c.g., Missouri P.R.R. v. McKinney, 189 Ark. 69, 71 S.W.2d 180 (1934); Georgis R. \& B. Co. v. Fuller, 6 Ga. App. 454, 65 S.E. 313 (1909); Doyle v. Portland R.L. \& P. Co, 71 Ore. 576, $143 \mathrm{Pac} 623$ (1914); Smith v. Philadelphia \& R.R.R., 274 Pa. 97, 117 Atl. 786 
Despite occasional misleading language, ${ }^{220}$ most of the actual decisions do turn on likelihood of presence, and this is as it should be. ${ }^{221}$ It should not make one whit of difference that defendant tried-vigorously or otherwiseto stop such trespassing, unless his efforts were successful enough to reduce the actual likelihood that people would trespass in fact. ${ }^{22}$ Such efforts might show lack of consent, but the occupier's consent is no longer determinative on this issue. ${ }^{223}$ This does not mean that the occupier will be deprived of the right of exclusive possession. He may still exclude the trespasser either by reasonable force or by legal action backed by the force of society. But it does mean that the right of exclusive possession does not carry with it the privilege to engage in conduct fraught with unreasonable probability of harm to the lives and limbs of people merely because there is no consent to their presence.

(1922) ; cases cited in Note, 167 A.L.R. 1253 (1947), which note also speaks in terms of "acquiescence" in stating the general rule. Id. at 1256. In most cases, however, there is no issue as to acquiescence, and it is allowed to be inferred from the extensive, open, and notorious use.

A few decisions have stressed the importance of acquiescence as a separate issuc, and have insisted on a separate determination of it where there is any conflict in the evidence. Felton v. Aubrey, 74 Fed. 350 (6th Cir. 1896); Jensen v. Utah Ry., 72 Utah 366, 270 Pac. 349 (1927) ; Smalley v. Rio Grande W.R.R., 34 Utah 423, 98 Pac. 311 (1908); Davis v. Chicago \& N.W.R.R., 58 Wisc. 646, 17 N.W. 406 (1883).

220. See, e.g., the holdings and the language in cases cited note 219 supra; sources cited notes 215-16 supra; Restatenent, ToRTs \$ 334 (1934).

221. "[A] developing law of negligence has battered continually at the gates gutarding the immunities of possessors of land. Compromise after compromise has been effected between the social value of human life and the social value of the unrestricted use of land. The last chapter is not yet written. . . In studying the cases the trouble too frequently is in the difference between what the courts say and what they decide. Too often the terminology is still in eighteenth or nineteenth century phrasing. Too often the tres* passer is dubbed something else to permit a recovery not countenanced by the outgrown rule." Eldredge, supra note 216 , at 34 .

222. In the following cases, unsuccessful efforts to stop trespassing did not avoid defendant's duty of care towards frequent trespassers. Great No. Ry. v. Thompson, 199 Fed. 395 (9th Cir. 1912) ; Southern R.R. v. Jones, 172 Ky. 8, 188 S.W. 873 (1916); Doyle v. Portland R.L. \& P. Co., 71 Ore. 576, 143 Pac. 623 (1914); Teakle v. San Pedro, L.A. \& S.L.R.R., 32 Utah 276, 90 Pac. 402 (1907) ; Brophy v. Milwaukee Electric Ry. \& Transport Co., 251 Wisc. 558, 30 N.W.2d 76 (1947). Cf. Restatenent, ToRTs $\$ 334$, comment $d$ (1934) ("no trespassing" signs are inadequate if defendant should know that they are in fact disregarded).

223. See sources cited note 216 sipra. If courts were really looking for the landowner's consent, they would be hesitant to imply it in cases where he simply does nothing to stop trespassing, since this is more apt to indicate the reluctant acceptance of an irremediable, but decidedly unwanted, situation than to show consent. And this is true whether consent be taken to refer to the occupier's state of mind or to conduct that leads others reasonably to conclude that he consents to their presence. See Bohlen, silpra note 215 , at 248; Eldredge, supra note 216, at 35; Restatensent, ToRTs $\$ 330$, comment $b$ (1934).

Of course, in any given case, defendant's acquiescence might point to an inference of consent. See Ehly v. Philadelphia \& R.R.R., 56 Pa. Super. 512 (1914) (a railroad, in fencing its property, leaves an opening where the public had beaten a path across the tracks). 